\title{
The cryptic seismic potential of blind faults revealed by off-fault geomorphology, Pichilemu, Chile.
}

Julius Jara-Muñoz ( $\square$ jara@geo.uni-potsdam.de )

University of Potsdam

\section{Daniel Melnick}

Austral University of Chile https://orcid.org/0000-0001-8397-7391

\section{Anne Socquet}

Univ. Grenoble Alpes, Univ. Savoie Mont Blanc, CNRS, IRD, IFSTTAR, ISTerre https://orcid.org/00000002-9208-7136

\section{Joaquin Cortés-Aranda}

Universidad de Concepcion

\section{Dominik Brill}

University Koeln

\section{Manfred Strecker}

Universität Potsdam

\section{Article}

Keywords: seismic hazards, seismic potential, blind faults, off-fault geomorphology, Pichilemu, Chile

Posted Date: October 7th, 2020

DOI: https://doi.org/10.21203/rs.3.rs-86121/v1

License: (9) This work is licensed under a Creative Commons Attribution 4.0 International License. Read Full License 


\section{The cryptic seismic potential of blind faults revealed by off-fault geomorphology, Pichilemu, Chile.}

J. Jara-Muñoz ${ }^{1,2 *}$, D. Melnick ${ }^{2,3}$, A. Socquet ${ }^{4}$, J. Cortés-Aranda ${ }^{2,5}$, D. Brill ${ }^{6}$, M. R. Strecker ${ }^{1}$

${ }^{1}$ Institute of Geosciences, University of Potsdam, Potsdam, Germany.

${ }^{2}$ Millennium Nucleus: The Seismic Cycle Along Subduction Zones, Valdivia, Chile.

${ }^{3}$ Instituto de Ciencias de la Tierra, TAQUACh, Universidad Austral de Chile, Valdivia, Chile.

${ }^{4}$ Université Grenoble Alpes, Université Savoie Mont Blanc, CNRS, IRD, IFSTTAR, ISTerre, Grenoble, France.

${ }^{5}$ Departamento de Ciencias de la Tierra, Universidad de Concepción, Concepción, Chile.

${ }^{6}$ Institute of Geography, University of Cologne, Germany.

email: jara@geo.uni-potsdam.de 


\begin{abstract}
In seismically-active regions, mapping capable faults and estimating their recurrence time is the first step to assess seismic hazards. Fault maps are commonly based on geologic and geomorphic features evident at the surface; however, mapping blind faults and estimating their seismic potential is challenging because on-fault diagnostic features are absent. Here, we study the Pichilemu Fault in coastal Chile, unknown until it generated a M7.0 earthquake in 2010. The lack of evident surface faulting suggests a partly-hidden blind fault. Using off-fault deformed marine terraces, we estimate a slip-rate of $0.42 \pm 0.04 \mathrm{~m} / \mathrm{ka}$, which when integrated with deformation estimated from satellite geodesy during the 2010 earthquake suggests a $2.5 \pm 0.25$ ka recurrence time for M6.6-6.9 extensional earthquakes. We propose that extension is associated with stress changes during megathrust earthquakes and accommodated by sporadic slip during upper-plate earthquakes. Our results have implications for assessing the seismic potential of cryptic faults along seismically-active coasts.
\end{abstract}




\section{Introduction}

The unexpected rupture of previously-unmapped faults during recent large-magnitude earthquakes emphasizes a major lacuna in our knowledge of the location and seismic potential of tectonically-active structures ${ }^{1}$. During the past decade, surface ruptures along unknown faults occurred during at least five $M>6$ earthquakes: 2010 Pichilemu, 2010 Darfield, 2016 Kaikoura, Christchurch, and 2019 Ridgecrest events ${ }^{2-6}$. These earthquakes highlight an important knowledge gap in seismogenesis and underscore the importance of deciphering the seismogenic nature of hidden faults in a variety of geodynamic environments. Mapping potentially-active faults commonly relies on the identification of geomorphic and geologic features indicative of surface deformation that may be associated with past earthquakes ${ }^{7-9}$. Nevertheless, such evidence may be completely absent or difficult to identify in areas affected by active blind faults e.g. ${ }^{10,11}$. Blind faults are geological structures whose ruptures do not reach the surface ${ }^{12}$, and therefore may have a hidden seismic potential. Such structures are common in sedimentary basins and have been identified from geophysical images e.g. ${ }^{13,14,15}$ and indirect geomorphic observations 16,17. However, estimating the seismic potential of blind faults is difficult using typical geologic and geomorphic evidence of surface ruptures during past earthquakes. Here we show that quantifying deformation using off-fault geomorphic strain markers provides valuable insight into potentially-active faults in coastal areas.

In subduction zones, the state of stress of the upper continental plate changes throughout the seismic cycle, both in space and polarity ${ }^{18}$. As a response to the drastic polarity change associated with a megathrust earthquake, the upper plate is commonly affected by enhanced extension promoting an increase in seismicity and occasionally triggered crustal 
earthquakes e.g. ${ }^{19,20}$. Slip on upper-plate faults triggered by megathrust earthquakes has been reported from Japan, Alaska, and Chile ${ }^{20-22}$, and has been inferred along most subduction zones e.g. ${ }^{20,23,24,25}$. However, historical and paleoseismic observations suggest that slowly-slipping crustal faults are characterized by recurrence times involving thousands of years, and therefore may not be reactivated during every megathrust earthquake, which commonly recur over several decades to a few centuries e.g. ${ }^{20,24,26}$. Because upper-plate faults are widespread along coasts bordering subduction zones, they may pose local hidden hazards. In addition, such crustal faults may produce higheramplitude seismic waves at local scales than megathrust earthquakes and may locally enhance the amplitude and shorten arrival times of tsunamis in the near-field e.g. ${ }^{27}$. Therefore, mapping crustal structures along subduction zones and quantifying their sliprate and relation with the megathrust earthquake cycle is a fundamental task to adequately assess the spatiotemporal characteristic of earthquake and tsunami hazards.

In this study we focus on the Pichilemu Fault (PIF), a partly-blind, hidden fault, which was unknown until it generated two shallow $\mathrm{Mw} 7$ and 6.9 earthquakes 11 days after the M8.8 Maule megathrust event that affected central Chile in 2010. We show that on-fault displaced geomorphic markers are absent along the fault trace, but that off-fault strain markers may be used to estimate a long-term slip-rate, which when integrated over the 2010 coseismic deformation pattern yields a recurrence rate of such earthquakes. Our results show the hidden potential of blind faults with implications for seismic hazards along coastlines bordering subduction zones.

\section{Seismotectonic and geologic setting of the Pichilemu Fault}


The PIF is located at the central Chile margin, where the Nazca plate is subducted underneath South America at $66 \mathrm{~mm} / \mathrm{yr}^{28}$. This region comprises the Coastal Range that reaches maximum elevations of $\sim 600 \mathrm{~m}$ and formed almost exclusively by crystalline metamorphic rocks, related to a Paleozoic accretionary prism overprinted by brittle deformation during Mesozoic and Cenozoic exhumation ${ }^{29-31}$. The seawards slope of the range has a sequence of uplifted marine terraces, some of them overlain by shallow marine deposits ${ }^{32}$. The dense vegetation and thick soil cover have hampered mapping of geological and geomorphic features in this area, resulting in different interpretations regarding the presence of neotectonic structures e.g. ${ }^{3,32}$.

The Pichilemu area was affected by the 2010 Maule earthquake (M8.8), which ruptured a 500-km-long portion of the megathrust with a peak slip of $17 \mathrm{~m}$ south of the PIF (Fig. 1A) e.g., ${ }^{33}$. The Maule earthquake triggered slip along the Santa Maria and Pichilemu coastal faults, located in the southern and northern parts of the rupture zone, respectively 3,21 (Fig. 1A). Before the 2010 earthquake, only a few faults affecting the crystalline basement and Cenozoic sedimentary cover had been previously mapped in this area 31,34 (Fig. 1B); the PIF was unknown.

Eleven days after the Maule earthquake, the PIF slipped during two M6.9 and 7 normalfaulting earthquakes (Fig. 1B), followed by $\sim 12,000$ aftershocks located between the plate interface and $\sim 4 \mathrm{~km}$ depth ${ }^{35}$ (Fig. 1C). Aftershocks delineated a NW-striking and SWdipping structure extending for $\sim 80 \mathrm{~km}$ along strike. Surface displacements estimated from GPS and ALOS/PALSAR Interferometric synthetic aperture radar (InSAR) collected 2 days before and 44 days after the Maule earthquake, suggest that the 2010 earthquakes were associated with a maximum slip of $\sim 3 \mathrm{~m}$ along the main strand of the PIF, extending from 0 to $22 \mathrm{~km}$ depth ${ }^{36}$. However, despite the large magnitude of these earthquakes, no 
evidences of surface ruptures were neither found during field surveys nor detected in radar interferometry images ${ }^{3,36}$, which suggests the PIF is a blind, yet active structure.

\section{Results}

\subsection{On-fault tectonic geomorphology from bare-earth LiDAR topography}

We used a Digital Terrain Model (DTM) derived from airborne Light Detection And Ranging (LiDAR) data at 1-m resolution to estimate fluvial metrics ${ }^{37}$ and analyse the surface expressions of the PIF (See methods section). The coastal reaches of the PIF comprise two catchments of $\sim 100 \mathrm{~km}^{2}$ each ( $\mathrm{C} 1$ and $\mathrm{C} 2$; Fig. 2A). A conspicuous set of NW-SE-oriented, subparallel lineaments exist in catchment $\mathrm{C} 1$ and extend for $\sim 9 \mathrm{~km}$; these are associated with aligned drainages and slope breaks (Fig. 2A and Fig. S1). The catchments are developed entirely on the metamorphic bedrock, except near the coastline where the valley floors are filled by marine, fluvial and eolian deposits. The catchment asymmetry is manifested in the deviation between the position of the main river trunk stream and the catchment centreline (Fig. 2A). The asymmetry of $\mathrm{C} 1$ and $\mathrm{C} 2$ is highlighted by trunk streams that converge along a section parallel to the edge of densely aligned aftershock seismicity and diverge from the catchment centreline in opposite directions (Fig. 2A). Catchment $\mathrm{C} 1$ is characterized by higher relief, with drainages reaching $\sim 500 \mathrm{~m}$ above mean sea level (amsl) and 16 knickpoints distributed between 100 and $350 \mathrm{~m}$ amsl. Steepness index (Ksn) values reach 100, and the higher Ksn values form a fringe at elevations between 300 and $400 \mathrm{~m}$ amsl (Fig. 2A). In turn, C2 comprises 8 knickpoints distributed between 100 and $150 \mathrm{~m}$ amsl and Ksn values reaching 70 .

Catchment and drainage metrics suggest variable surface deformation in this area. For instance, the marked catchment asymmetry suggests local block tilting of the PIF footwall 
and hanging-wall blocks. In addition, differences in Ksn, knickpoint locations, and drainage elevations may be indicative of differential vertical displacements (Fig. 2A-D). However, a detailed analysis of the PIF lineaments suggests that these features cannot be directly interpreted as fault scarps associated with surface breaks during recent earthquakes. Slope and elevation breaks are neither observed on maximum elevations derived from swath profiles nor on ridge-crest profiles (Figs. 2E and 2F). In addition, no clear relationship exists between the trace of these lineaments and the fringe of higher Ksn values of $\mathrm{C} 1$ regarding overlap or orientation (Fig. 2A).

Chi-plots are commonly used to identify transient signals propagating upstream along fluvial systems, such as tectonically-generated knickpoints ${ }^{38}$ (See Section 4.2 for further details). We found no relationship between chi-plot $(\chi)$ values at the location of the knickpoints and their distance to the mapped lineaments (Figs. 2B and S2, Methods). Furthermore, the distance between knickpoints and lineaments is rather uniform (Fig. 2B), suggesting that knickpoints are not related to active fault scarps, and rather reflect baselevel changes associated with relative sea-level variations. The results of morphometric analyses of LiDAR topography suggests that the area has been affected by surfacedeformation processes with a certain degree of spatial asymmetry, which may reflect tilting and differential uplift. However, these deformation patterns cannot be directly associated with any structure that has a marked surface expression. We therefore conclude that this area is not characterized by localized deformation at the surface, but rather by strain distributed over a 10-km-wide region.

\subsection{Off-fault tectonic geomorphology: deformed marine terraces}


Marine terraces - geomorphic markers of past relative sea-level positions ${ }^{39}$ - are ubiquitous along the coast of central Chile ${ }^{32}$. We mapped terraces at Pichilemu using a LiDAR DTM and the TerraceM-2 software ${ }^{40}$ (Fig. 3A, Methods). South of the PIF, four levels of wave-cut terraces sculpted into the bedrock reach up to $100 \mathrm{~m}$ elevation (Figs. 3B and S3), and are occasionally covered by a thin veneer of marine and eolian sediments. In turn, North of the PIF, six distinct sedimentary units correspond to wave-built terraces; they consist of marine sandstone bodies onlapping against the crystalline bedrock at elevations between 50 and $170 \mathrm{~m}$ (Fig. 3B), each one comprising a single regressive cycle (Fig. S4).

North of the PIF, we obtained post-IR IRSL (post-infrared infrared stimulated luminescence, Methods) ages of $106 \pm 9$ and $297 \pm 29 \mathrm{ka}$ from marine sediments of the lower and intermediate levels at 51 and $115 \mathrm{~m}$ amsl, respectively, corresponding to Marine Isotope Stages (MIS) 5c and 8 (Figs. 3A, S4, S5, and S6). These sediments were deposited above bedrock during shoreline progradation shortly after the corresponding MIS highstand e.g. ${ }^{32}$; thus, we correlate the surface morphology and geometry of these deposits with MIS 5e and MIS 9, at 125 and 320 ka respectively (Figs. 3A, 3B, S4, and S6). We tentatively correlate two additional terrace levels with MIS 7 and MIS 11, between 250 and 380 ka (See Fig. S6). South of the PIF, the lower marine terrace level is continuously exposed between Punta de Lobos and La Puntilla, with widths of 1 to $3 \mathrm{~km}$. These surfaces have been interpreted as a rasas ${ }^{32}$, i.e. terrace surfaces formed by reoccupation during successive highstands. Marine sediments that cover this rasa level are exposed at 16 and $32 \mathrm{~m}$ amsl and yielded post-IR IRSL ages of $328 \pm 33$ and $314 \pm 30 \mathrm{ka}$, corresponding to MIS 9 (Figs. S3, and S6). The upper terrace levels are characterized by sharply defined paleo-cliffs and narrow paleo-platforms, with mean shoreline angle 
elevations at 42, 60, and $80 \mathrm{~m}$ and whose elevation decreases southward. We interpret the age of the three upper terrace levels to range between MIS 11 and 19 by correlating the sequence with a global sea-level curve of Rohling et al. ${ }^{41}$ and Bintanja et al. ${ }^{42}$ (See methods and Fig. S6).

The estimated uplift rates vary from $0.06-0.15 \mathrm{~m} / \mathrm{ka}$ to $0.37-0.46 \mathrm{~m} / \mathrm{ka}$ across the PIF (Fig $3 \mathrm{C}$ ), with associated $2 \mathrm{~s}$ errors between 0.01 and $0.08 \mathrm{~m} / \mathrm{ka}$, suggesting protracted emergence over the past $\sim 620 \mathrm{ka}$. Overall, the marine terrace sequence displays a broad warping pattern of $\sim 10 \mathrm{~km}$ wavelength, which is compatible with faster uplift and back tilting along the PIF foot wall block, and monoclinal roll-over folding in the hanging wall, which is consistent with a NW-striking, SW-dipping normal fault (Figs. 3B and 3C).

\subsection{Coseismic slip and long-term slip-rate of the PIF}

Using a combination of coseismic displacements derived from GPS and InSAR we estimated slip along the PIF during the 2010 earthquakes (Figs. 3D and S7, Methods). Following the inferred presence of a secondary synthetic fault south of the PIF ${ }^{36}$, we performed modelling experiments with one and two faults using fault geometries estimated from spatial alignments of crustal seismicity (Fig. S8). We estimated fault deformation parameters by iterating slip magnitude and up- and down-dip depth values (Fig. S9), and quantifying the respective uncertainties (Fig. S10). We reproduced the pattern of surface deformation with $1.05 \mathrm{~m}$ of slip $(90 \%$ confidence interval between 0.9 and $1.4 \mathrm{~m}$ ) along the main strand of the PIF (F1, Fig. 4A and 4B), at depths between 26.2 and $4.4 \mathrm{~km}$ (Figs. S9 and S10B). These results cannot be distinguished from those obtained from a least-square inversion of the InSAR-derived surface displacement field 
(Fig. S11). The down-dip extent of our model results is consistent with the depth to the plate interface in the SLAB2.0 model $^{43}$.

We estimated a long-term slip-rate for the PIF (over the past $\sim 500 \mathrm{ka}$ ) by forward modelling the spatial pattern of uplift rates estimated from marine terraces. We modelled surface deformation associated with two faults (F1 and F2; Figs. 4C and 4D), which evidently offset the deformation pattern inferred from marine terraces. We generated two models, the first one was based on uplift rates estimated from measured shoreline angles, and the second ones was based on a smoothed surface derived from the interpolation of these measurements, which increases the area for comparing measured and modelled results. In the first model we obtained a slip-rate of $0.42+0.05-0.03 \mathrm{~m} / \mathrm{ka}$ for $\mathrm{F} 1(90 \%$ confidence) (Fig. 4C and 4D), for a fault extending from 26 to $0.4 \mathrm{~km}$ depth (Fig. S9B, $\mathrm{S} 10 \mathrm{D}$ and S10E), and $0.06+0.07-0.03 \mathrm{~m} / \mathrm{ka}$ for F2 with an updip depth of $1.0 \mathrm{~km}$. The second model yielded a slip-rate of $0.42 \pm 0.04 \mathrm{~m} / \mathrm{ka}$ for F1 (Fig. 4C and 4D) and 0.08 $+0.07-0.02 \mathrm{~m} / \mathrm{ka}$ for F2. The best-fit updip slip depths are 0.8 and $1.2 \mathrm{~km}$ for F1 and F2, respectively (Figs. S9C, S10G and S10H). Importantly, both models predict similar deformation patterns and slip rates, with slip not reaching the surface. We select the second as the best-fit model that better reproduces the deformation pattern of marine terraces with lower uncertainty (Fig. 4D).

Our coseismic and long-term slip models suggest blind faulting with similar surface deformation patterns. The differences in updip depths between both models may be related to the relatively simple model setups, which assumes heterogeneous slip along a planar fault slip with homogeneous rheology. However, both models reproduce well the pattern and magnitude of surface displacements well, suggesting that deformation associated with the PIF occurs along a 10-km-wide area. 


\section{Discussion}

\subsection{Earthquake recurrence of the Pichilemu Fault}

Coseismic and long-term surface deformation patterns of the PIF are similar, and both are consistent with extensional fault kinematics. We therefore propose that the PIF accrues permanent deformation only during triggered slip by megathrust earthquakes, such as during the events observed after the Maule earthquake. Historical and paleoseismic records suggest a recurrence time of $\sim 0.1-0.2$ ka for Maule-type events ${ }^{44,45}$, whereas paleo-tsunami records suggest recurrence times of $0.16 \mathrm{ka}$ at the southern tip of the rupture ${ }^{46}$. If we consider a recurrence time of $0.2 \mathrm{ka}$, then a triggered slip of $0.084 \mathrm{~m}$ would account for the long-term PIF slip-rate (Fig. 5A); such slip would be equivalent to a seismic moment between $7.943 \times 10^{16}$ and $1.258 \times 10^{18} \mathrm{Nm}$ or a Mw 5.2 to 6 earthquake, based on empirical relationships ${ }^{47-49}$ (Fig. 5B). In turn, a recurrence time of 0.5 ka would imply $0.21 \mathrm{~m}$ of slip along the PIF (Fig. 5A) and an earthquake magnitude between $\mathrm{Mw}$ 5.7 and 6.3 (Fig. 5B). In both cases the estimated slip per event would be five to ten times less than during the 2010 PIF earthquakes. Instead, in order to trigger a Mw 7 earthquake, $1.65 \mathrm{~m}$ of slip per event would be necessary. In this case, the recurrence time required to account for the long-term slip-rate would be $3.9 \mathrm{ka}$. If the probability distributions of the long-term PIF slip-rate and coseismic slip intersect, a recurrence time of $2.5 \mathrm{ka}$ (2.1 to 3.3 ka at $95 \%$ confidence interval) may be inferred (Fig. 5A). Such a recurrence time would generate a Mw 6.6 to 6.9 earthquake, equivalent to a seismic moment release between 1.0 and $2.8 \times 10^{19} \mathrm{Nm}$ (Fig. 5B), similar to the 2010 PIF earthquakes. Our results suggest that the recurrence time of the PIF may be over an order of magnitude greater than that of $\mathrm{M}>8$ megathrust earthquakes in the Maule segment, implying sporadic slip triggering. 


\subsection{Pichilemu Fault triggering by megathrust earthquakes}

Stress transferred to the upper plate after a megathrust earthquake may induce reactivation of crustal faults optimally oriented with respect to the new stress field e.g. ${ }^{50}$. Here, we model the Coulomb failure stress (CFS) induced by different slip distributions during megathrust earthquakes on the PIF to explore the range of triggered reactivation scenarios. The Maule earthquake involved two main patches of slip at the northern and southern part of the rupture ${ }^{33}$. Coseismic slip along the southern patch would result in negative CFS values (-0.003 MPa) that would inhibit reactivation of the PIF (Fig. 5C). Conversely, slip along the northern patch would result in positive CFS values between 0.3 and $0.4 \mathrm{MPa}$ (Fig. 5C), which is similar to the positive CFS values (0.33 MPa) attained during the Maule earthquake that promoted the reactivation of PIF (Fig. 5C). Model results based on geophysical and paleoseismological observations along the Andean margin suggest that

the heterogeneous frictional properties of the subduction megathrust may result in temporally variable slip patterns e.g. ${ }^{51,52}$. To test such a scenario, we generate synthetic slip distributions at different locations along the strike of the Maule earthquake rupture (Fig. S12). We noticed that as the locus of slip shifted northwards, CFS values at the PIF increase progressively, reaching a maximum of 0.23 to $0.34 \mathrm{MPa}$ for friction coefficients between 0.4 and 0.75 (Fig. 5C). This result is similar as the CFS induced by slip along the northern and southern parts of the rupture, in both cases PIF reactivation will be favoured when megathrust slip occurs in the vicinity of the fault, at the northern part of the Maule rupture.

It has been suggested that the along-dip segmentation of megathrusts may control the magnitude and characteristics of subduction earthquakes ${ }^{53}$. We compared CFS at the PIF 
induced by earthquakes occurring at variable megathrust down-dip depths by simulating synthetic slip scenarios (Fig. S12). Previous studies have shown that stress-field perturbations of 0.1 to $0.3 \mathrm{MPa}$ may be sufficient to trigger seismicity, while reductions of the same amount may prevent them ${ }^{54-56}$. Certainly, the threshold of stresses for fault reactivation will mostly depend on the amount of elastic strain accumulated by the fault; however, for the purpose of comparison we set a tentative CFS threshold at $0.2 \mathrm{MPa}$, which is below the minimum induced at the PIF during the Maule earthquake. We observe that when the locus of slip is located deeper down-dip along the megathrust (between 40 and $85 \mathrm{~km}$ depth), CFS values decrease (from 0.18 to $0.01 \mathrm{MPa}$ ) below the reactivation threshold (Fig. 5D). When the locus of slip is located at shallower depths (15 to $40 \mathrm{~km}$ depth), CFS values increase reaching 0.28 to $0.35 \mathrm{MPa}$, within the tensional stress scenario that may promote reactivation of the PIF (Fig. 5D). However, megathrust slip at depths shallower than $\sim 15 \mathrm{~km}$ decreases CFS on the PIF, reaching values near the proposed CFS threshold for reactivation (Fig. 5D). The comparison of different scenarios suggests that triggered reactivation of the PIF will be favoured when megathrust slip is located in the vicinity of its down-dip extent.

The CFS modelling shows that different slip distributions along the megathrust may control the reactivation potential of the PIF, promoting or inhibiting its reactivation. These results may explain why the estimated $2.5 \mathrm{ka}$ recurrence time of the PIF is longer than expected for megathrust earthquakes in the Maule segment. We consider two possible scenarios to explain this:

1) The Maule segment may be characterized by variable slip during megathrustearthquake ruptures. In this case megathrust earthquakes may trigger the reactivation of PIF when the PIF is favourably oriented to the megathrust slip pattern, which may occur 
occasionally. During the interseismic phase of the megathrust earthquake cycle, the PIF would accumulate elastic strain.

2) The Maule segment may be characterized by persistent earthquake ruptures. In this case, positive CFS values induced by successive earthquakes may build up tensional stresses on the PIF, which may be reactivated only when enough elastic strain has been accumulated and when the fault is favourably oriented to the stress field. A minimum amount of elastic strain accumulates during the interseismic phase, counteracting tensional stresses.

Regarding the first scenario, the relation between the coseismic slip distribution during the Maule earthquake and long-term deformation and the observed geophysical characteristics suggests three persistent segments ${ }^{32,57}$; however, the magnitude of coseismic slip on these segments may vary between cycles ${ }^{57}$. Furthermore, the CFS values on the PIF are negative during the interseismic period that preceded the Maule earthquake ${ }^{33}$ (Figs. 5A and B) suggesting no elastic strain is expected to be accumulated during the interseismic phase. Regarding the second scenario, a similar interpretation has been proposed to explain the reactivation of crustal faults in northern Chile ${ }^{58}$, where negative CFS during the interseismic stage may counterbalance the CFS induced by coseismic slip, extending the recurrence time of crustal fault earthquakes and providing an explanation for the long recurrence times that we estimated for PIF earthquakes.

\subsection{Origin of the PIF and implications for blind faults}

Blind faults mostly occur in sedimentary basins, when fault tip propagation fails to reach the surface across a thick sedimentary cover ${ }^{59}$. This is, however, not the case of the PIF, 
which mostly affects crystalline basement rocks. On the other hand, blind structures may be also controlled by mechanical and rheological heterogeneities in the upper crust e.g. ${ }^{59}$. The PIF host rocks are part of a Palaeozoic accretionary wedge characterized with pervasively-deformed high-pressure metasedimentary and metavolcanics rocks locally forming melanges ${ }^{29-31}$. These metamorphic rocks are overprinted by brittle deformation during Cenozoic exhumation resulting in a rheologically heterogeneous and fragmented upper crust. We propose that this rheological heterogeneity may have preconditioned blind faulting by favouring strain diffusion across a wide deformation zone in the uppermost crustal levels, preventing localized surface faulting. This assessment is further supported by the distribution of aftershock seismicity following the 2010 earthquakes across a ${ }^{\sim} 10-\mathrm{km}-$ wide fringe (Fig. $1 \mathrm{C}$ and S8), and by a sharp increase in p-wave velocity at ${ }^{\sim} 1-\mathrm{km}$ depth inferred from seismic tomography ${ }^{60}$. We suggest that the lineaments observed in the LiDAR topography may represent secondary fault tip bending structures, inherited from old crustal fabrics and with very low displacement rates, which are insufficient to create and preserve morphological evidences of surface faulting.

The potential role of heterogeneity in upper-crustal rheology in favouring or limiting surface-reaching faulting is further highlighted by the characteristics of the El Yolki fault, $125 \mathrm{~km}$ to the south, which has a similar kinematics and orientation as the PIF ${ }^{57}$. In contrast to 
the PIF, the El Yolki Fault is not a blind structure and is associated with surface-breaching faulting. The surrounding metamorphic basement rocks consist exclusively of metapelites that are not strongly deformed and only display subhorizontal foliation ${ }^{31}$. This homogeneous rheology might therefore promote the localization of strain along the fault zone and towards the surface.

Unlike the megathrust, crustal-scale faults in the upper plate of subduction zones may remain inactive for long periods, in most cases not detectable by geodetic or seismic monitoring ${ }^{61}$. Furthermore, if we consider that some of these faults may be blind and lacking of clear geomorphic expression, such as the PIF, their unambiguous identification, in the field or with the help of remote sensing, becomes even more challenging. Many of such cryptic crustal faults in subduction zones have only been recognized after their seismic reactivation, raising questions on the number of active faults with the potential to produce large earthquakes that still remain to be recognized. For example, a statistical analysis of historical crustal earthquakes in New Zealand showed that more than half of large earthquakes ruptured previously unidentified faults ${ }^{1}$. Further cryptic and partly hidden active faults have been documented in Cascadia ${ }^{62,63}$ and Japan ${ }^{64,65}$, and are expected to exist along other subduction zones. Regional acquisition of LiDAR topography coupled with quantitative analyses of geomorphic markers may ultimately help increase our knowledge about the location, deformation mechanisms, and recurrence time of hitherto unidentified seismogenic faults, with implications for seismic and tsunami hazards. 


\section{Materials and Methods}

\subsection{Estimating coseismic slip}

We processed two Envisat ${ }^{\circledR}$ scenes obtained 2 days before and 7 days after the March 11 2010 earthquake doublet, obtaining line-of-sight (LOS) displacements (Fig. S7 and Table S1). To corroborate our results, we compared the LOS surface displacements with displacements estimated using positions of the permanent GPS station PICH (location in Fig. 3D) projected to the LOS vector. To estimate coseismic slip along the PIF, we searched for the parameters that better reproduced the distribution of LOS displacements using forward elastic dislocation modelling ${ }^{66}$. The elastic dislocation models were programmed in Matlab ${ }^{\circledR}$ using the function okada85 ${ }^{6}{ }^{67}$. We inferred fault geometries from alignments in the cluster of crustal aftershocks associated with the PIF earthquakes ( $76^{\circ}$ dip, N41 ${ }^{\circ} \mathrm{W}$ strike and $80 \mathrm{~km}$ length) (Fig. S8). The strike inferred from aftershocks is similar than previous interpretations and fault planes from focal mechanisms ${ }^{36}$ and to the strike of lineaments mapped using the LiDAR bare-earth topography. To compare between model and observations we iterate the slip, updip, and down-dip for defined ranges and constant increments, generating 68.921 models (Figs. S9A and S10), and searching from the parameters that minimized the Normalized Mean Root Square Error (NRMSE).

Eq.1: $\quad R \quad R S=\sqrt{\frac{\sum_{i=1}^{n}(y i-y)^{2}}{n}}$

The root mean squared error (RMSE) is defined by the difference between observation $(y i)$ and model $(y), n$ is the number of observations (Eq.1). 
Eq. 2: $\quad N R M S E=\frac{R M S E}{(y \max -y \min )}$

The NRMSE facilitates comparing models with different scales by normalizing the RMSE (Eq. 2), where $y$ max-y min is the range of observations. The uncertainties in model results were estimated using the lower 5\% tail of the NRMSE distribution (Fig S10). We estimated slip values using this tail distribution and define the model uncertainty as the interval between the 5\% and 95\% percentiles (Fig. S10).

To evaluate the consistency of fault slip estimates, we compared our result with a 3D slip inversion of the coseismic displacement field estimated from InSAR data (Fig. S11). For the inversion we used the elastic dislocation model and the surface deformation constrained by InSAR, the fault geometry from focal mechanisms of the Pichilemu earthquakes, and a Poisson ratio of 0.25 following previous studies in the region ${ }^{57,58}$. To solve for the slip distribution, we used a least squares minimization determining the bestfit solution that reproduce the InSAR deformation patterns.

\subsection{Analysis of on-fault geomorphic features in the Pichilemu area}

We performed a detailed geomorphic and morphometric analysis of off- and on-fault geomorphic features in the PIF area. On-fault features where searched by analyzing topographic and fluvial metrics using the Topotoolbox-2 software ${ }^{37}$. We created red-relief maps (RRM) based on Chiba et al. ${ }^{68}$, which uses the terrain openness and surface slope. RRM are useful to search for lineaments and to identify fault scarps as well as changes in the fluvial network because these maps lack the potential bias of light source direction in common shaded relief images (Fig. S1). 
Drainage and catchment morphology have the potential to be used as tectonic markers in the quantification of regional strain, uplift, and tilting. Ideally, catchments should be symmetric about the main trunk stream if they have incised a horizontal surface of uniform lithology in homogeneous climatic conditions ${ }^{69}$. To estimate the catchment asymmetry, we extracted the main catchments and drainage network in the Pichilemu area using the flow routing and accumulation algorithms of Topotoolbox ${ }^{\circledR}{ }^{37}$ for manually defined outlet locations of each catchment. Then, we estimated the catchment centreline by creating a distance buffer from the border of each catchment polygon. A distance matrix is skeletonized using plain curvature to obtain the centreline and its position is compared with the main trunk stream to estimate the catchment asymmetry.

The steepness index (Ksn) may be useful to obtain information on tectonic and/or climatic perturbations in a fluvial network. Ksn values allow quantifying deviations from the steady-state river concavity and detect the location of these deviations along the stream network. The estimation of Ksn values is based on the power law of detachment-limited incision into bedrock ${ }^{70}$.

Eq.3: $\quad \quad \frac{d z}{d t}=U-k A^{m}\left(\frac{d z}{d x}\right)^{n}$

Where $U$ is the uplift rate, $A$ is the upslope area, $d z / d x$ is the channel slope and $m, k$ and $n$ are constants. In steady state conditions $\mathrm{dz} / \mathrm{dt}=0$, hence we can rearrange the equation as:

Eq.4: $\quad \frac{d z}{d x}=\left(\frac{U}{k}\right)^{\frac{1}{n}} A^{\frac{-m}{n}}$ 
Were $(\mathrm{U} / \mathrm{K})^{1 / \mathrm{n}}$ represents the channel steepness and $\mathrm{m} / \mathrm{n}$ is the channel concavity $(\bar{\theta})$, thus the equation can be written as:

Eq. 5: $\quad K s n=\frac{S}{A^{-\theta}}$

In contrast to Ksn, chi-plots are based on the horizontal transform of the upslope area to linearize the concave upward profile for a well-chosen reference concavity. This spatial transform makes chi-plots useful to identify transient erosional signals with a common origin propagating upstream along fluvial systems, such as tectonically-generated knickpoints or changes in base level. Furthermore, the chi dimension allows comparing these signals between different catchments independently of their size or shape.

Determining chi-values requires rearranging Eq. 4 to convert dx to a distance measured from the catchment outlet and assuming that $\mathrm{U}$ and $\mathrm{k}$ are spatially uniform:

Eq. 6:

$$
\int \frac{d z}{d x} d x=z(x 0)+\left(\frac{U}{k A 0^{m}}\right)^{\frac{1}{n}} \int \frac{A 0}{A(x)^{\frac{m}{n}}} d x
$$

The integral of $\mathrm{dz} / \mathrm{dx}$ is calculated using a reference area $(\mathrm{A} 0)$, where $\mathrm{x} 0$ is the catchment outlet. The chi-plot values $(\chi)$ are estimated based on the right hand-integral:

Eq. 7: $\quad \chi=\int\left(\frac{A 0}{A(x)}\right)^{\frac{m}{n}} d x$ 
To calculate the Ksn and chi-values in the catchments of the Pichilemu area we used Topotoolbox ${ }^{\circledR}{ }^{37}$, which includes all the indicated equations. We used a reference concavity of 0.45 .

\subsection{Analysis of off-fault geomorphic features in the Pichilemu area}

To analyse off-fault geomorphic features, we studied marine terraces using two methods depending on their type and characteristics:

\subsubsection{Analysis of wave-built terraces}

We analysed wave-built marine terraces following ${ }^{71}$ considering the morphology of the bedrock unconformity, number of sedimentary cycles within the wave-built terrace, and thickness of the sequence. We mapped the surface morphology of the wave-built terraces using swath profiles to detect slope breaks. In addition, we measured the depth to the crystalline bedrock in incised valleys and generated an isopach map of sedimentary sequence thickness (Fig. S4). This allows differentiating sedimentary sequences and improving the estimation of shoreline angle elevations.

\subsubsection{Analysis of wave-cut terraces}

We studied the surface morphology of marine terraces using LiDAR topography and swath profiles, in order to measure the location and elevation of the shoreline angle. The shoreline angle is a geomorphic marker located at the intersection between the paleoplatform and paleo-cliff that represent the maximum reach of the sea level during a highstand period that can be used to estimate vertical deformation and coastal uplift rates 
39. To estimate uplift rates $(u)$, we correlated terrace levels and sea-level highstands using the IRSL ages and a sea-level curve for the southern hemisphere spanning the last $700 \mathrm{ka}$ 41,42 following Lajoie ${ }^{39}$ as:

Eq.8: $u=\longdiv { ( E - e ) / T }$

where $E$ is the elevation of shoreline angles, $(e)$ the position of the respective highstand and $T$ the age of the terrace level. Uplift rate errors are estimated following Gallen et al., ${ }^{72}$ as:

Eq. 9: $\overline{\operatorname{Se}(u)^{2}}=u^{2}\left(\left(\sigma^{2} H / H_{H^{2}}\right)+\left(\sigma^{2} T / T^{2}\right)\right)$

where $\sigma \mathrm{H}$ is the error in relative sea-level defined as:

Eq. $10: \sigma \mathrm{H}=\sqrt{\sigma E^{2}+\sigma e^{2}}$

where $\sigma T$ is the age uncertainty in the sea-level curve, $\sigma E$ is the error of the shoreline angle assessments and $\sigma e$ is $12 \mathrm{~m}$ uncertainty of the highstand elevation based on Rohling et al. 41. We used an arbitrary uncertainty of $7 \mathrm{ka}$ for the duration of the highstands $(\sigma T)$ following a previous study e.g. ${ }^{32}$.

\subsubsection{Post-IR IRSL dating}

Four samples for thermoluminescence dating were analyzed at the University of Cologne using the post-IR IRSL signal of K-feldspar obtained from marine terrace sediments. We selected sedimentary units for dating using three criteria: 1) sedimentary units formed by shallow marine sediments, preferable from berm or swash zone environments. 2) Sandy sediments of medium grain sizes with more than $20 \%$ of feldspars. 3) Samples from the base of the sequence as near as possible to the bedrock wave-cut platform (Fig. S3). We 
analyzed medium sand K-Feldspar grains $(100-250 \mu \mathrm{m})$ following the post-IR IRSL 290 SAR protocol ${ }^{73}$. The dated sediments were in general characterized by high feldspar signals with adequate reproducibility in dose recovery tests performed after signal resetting in a solar simulator for $12 \mathrm{~h}$ (satisfactory ratios between measured and laboratory dose between 0.9 - 1.1). Burial doses were based on 5 - 19 aliquots of $8 \mathrm{~mm}$ diameter and using the central age model (CAM) of Galbraith et al. ${ }^{74}$ for calculation (See radial plots inf Fig. S5). In addition, we evaluated the completeness of signal resetting using a sample from a modern beach berm (Sample SM mb, Table 1), which revealed a residual dose insignificant compared to the burial doses of the marine terrace samples (i.e. $\sim 3.4$ Gy). Radionuclide analysis (uranium, thorium and potassium) for dose-rate estimation was carried out using high-resolution gamma-spectrometry to estimate the dose rate (See details in Table 1). To estimate internal dose rates we used a potassium content of $12.5 \pm 0.5 \%$ based on the method proposed by Huntley and Baril ${ }^{75}$.

\subsubsection{Slip-rate of the PIF from deformed marine terraces}

We determined the PIF slip-rate by searching the best-fitting input parameters from a set of 83.521 model runs to find the minimum NRMSE value (Fig. S9B and S9C, Eq. 2). Uplift rates derived from shoreline angle elevations of marine terraces were reproduced by forward elastic dislocation models by varying up- and down-dip slip depths and the sliprate of each fault. The elastic model setups include the same geometry and down-dip depth used in coseismic models. We performed preliminary modelling experiments using one and two faults, obtaining a better result using two faults (Fig. 4D). To perform the comparisons, we iterated the slip magnitude and updip depths of F1 and F2 using constant increments. The best-fitting models were selected from the minimum NRMSE value. To 
estimate the confidence interval of the best-fit models, we used the lower $5 \%$ tail of the NRMSE distribution (Fig. S10) to calculate slip and slip rates. From these distributions, we define the $5 \%$ and $95 \%$ percentiles as the confidence limits, equivalent to a $90 \%$ confidence interval, as the uncertainty of the best-fit model results (Fig. S10).

Because marine terraces are exposed along the coast, they mostly reflect deformation along a 2D profile, and are therefore not suitable for estimating fault-slip with a 3D inverse model. In order to produce comparable results at the coseismic and long-term time-scales, and given that forward and inverse models of InSAR displacements produce similar results, we compare results using forward dislocation models.

\subsection{Modelling Coulomb stress failure}

We evaluate the reactivation potential of the PIF by a megathrust earthquake by analyzing the Coulomb Failure Stress (CFS). Coulomb stresses imparted by slip on a source fault

may promote or inhibit the reactivation of a receiver fault ${ }^{50}$. For this analysis we compared slip during the 2010 Maule earthquake and by simulating synthetic slip scenarios in elliptical patches of $100 \mathrm{~km}$ length and $50 \mathrm{~km}$ width (Fig. S12). We set the size and amount of slip of these synthetic slip patches based on the average slip distribution of the 2010 Maule earthquake. In a first set of modelling experiments, the locus of 28 synthetic slip patches was shifted along the Maule rupture zone between $38^{\circ}$ and $35^{\circ} \mathrm{S}$ and within the up- and down-dip depth limits of the Maule rupture ${ }^{33}$. In a second set, we shifted the locus of slip of 15 synthetic patches for different down-dip depths between 10 and $80 \mathrm{~km}$. This was done at the northern area of the Maule rupture, where triggering occurred in 2010. We modelled the CFS on the PIF using the fault geometry inferred from aftershocks (Fig. S8) and the Coulomb 3.4 algorithms ${ }^{76}$. The model setup 
and rheological parameters were based on previous studies in the South American margin and Maule region e.g. ${ }^{3,36,58}$, we used a Poisson's ratio of 0.25 and Young modulus of 75 GPa both based on average values for upper crustal materials ${ }^{76}$. The friction coefficient of crustal faults commonly varies over a large range ${ }^{58}$, and therefore our analysis considered a range of friction values between 0.4 and 0.75 . We explored the potential effect of interseismic plate-locking induced continental contraction on the PIF using a back-slip model based on the locking distribution of Moreno et al. ${ }^{33}$. We considered a plate convergence rate of $66 \mathrm{~mm} / \mathrm{yr}^{28}$ and assumed complete elastic strain release during the 1835 earthquake, which was similar in rupture area and magnitude to the 2010 Maule earthquake ${ }^{33}$.

\section{Acknowledgments}

We would like to thank Kenneth Fisk and Christian Hilleman for help in the field and Juan Gonzalez-Carrasco for suggestions on CFS modeling. Funding: This study was supported by the Millennium Scientific Initiative (ICM) of the Chilean government through grant NC160025 "Millennium Nucleus CYCLO The Seismic Cycle Along Subduction Zones," Chilean National Fund for Development of Science and Technology (FONDECYT) grants 1150321, 1181479, and 1190258, ANID PIA Anillo ACT192169, and German Science Foundation (DFG) grants ME 3157/4-2, JA 2860/1-1, and STR 373/30-1.

Author contributions: JJ-M and DM designed the project, JJ-M, DM and MRS performed fieldwork and sampling. AS acquired and processed ENVISAT radar images. JC-A supervised the CFS modelling. DB analysed IRSL samples and obtained ages. JJ-M and DM wrote the manuscript and all the authors participated in the discussion of results. 
Competing interests: The authors declare that they have no competing interests.

Data and materials availability: The data needed to evaluate the conclusions in the paper are present in the paper and/or the Supplementary Materials. Additional data related to this paper may be requested from the authors.

\section{References}

1 Nicol, A., Van Dissen, R., Stirling, M. \& Gerstenberger, M. Completeness of the paleoseismic active-fault record in New Zealand. Seismological Research Letters 87, 12991310 (2016).

2 Hollingsworth, J., Ye, L. \& Avouac, J. P. Dynamically triggered slip on a splay fault in the Mw 7.8, 2016 Kaikoura (New Zealand) earthquake. Geophysical Research Letters 44, $3517-3525$ (2017).

3 Farías, M., Comte, D., Roecker, S., Carrizo, D. \& Pardo, M. Crustal extensional faulting triggered by the 2010 Chilean earthquake: The Pichilemu Seismic Sequence. Tectonics 30, TC6010, doi:10.1029/2011tc002888 (2011).

4 Quigley, M. et al. Surface rupture during the $2010 \mathrm{Mw} 7.1$ Darfield (Canterbury) earthquake: Implications for fault rupture dynamics and seismic-hazard analysis. Geology 40, 55-58 (2012).

5 Beavan, J., Fielding, E., Motagh, M., Samsonov, S. \& Donnelly, N. Fault location and slip distribution of the 22 February $2011 \mathrm{Mw}$ 6.2 Christchurch, New Zealand, earthquake from geodetic data. Seismological Research Letters 82, 789-799 (2011).

6 Barnhart, W. D., Hayes, G. P. \& Gold, R. D. The July 2019 Ridgecrest, California, earthquake sequence: Kinematics of slip and stressing in cross-fault ruptures. Geophysical Research Letters 46, 11859-11867 (2019).

$7 \quad$ Kumar, S. et al. Paleoseismic evidence of great surface rupture earthquakes along the Indian Himalaya. Journal of Geophysical Research: Solid Earth 111, B03304 (2006).

8 Sherrod, B. L. et al. Holocene fault scarps near Tacoma, Washington, USA. Geology 32, 9-12 (2004). 
9 Zielke, O., Klinger, Y. \& Arrowsmith, J. R. Fault slip and earthquake recurrence along strike-slip faults - Contributions of high-resolution geomorphic data. Tectonophysics 638, 4362 (2015).

10 Burrato, P., Vannoli, P., Fracassi, U., Basili, R. \& Valensise, G. Is blind faulting truly invisible? Tectonic-controlled drainage evolution in the epicentral area of the May 2012, Emilia-Romagna earthquake sequence (northern Italy). Annals of Geophysics 55, 525-531 (2012).

11 Talebian, M. et al. The 2003 Bam (Iran) earthquake: Rupture of a blind strike-slip fault. Geophysical Research Letters 31, L11611 (2004).

12 Watterson, J. Fault dimensions, displacements and growth. Pure Applied Geophysics 124, 365-373 (1986).

13 Melnick, D., Bookhagen, B., Strecker, M. R. \& Echtler, H. P. Segmentation of megathrust rupture zones from fore-arc deformation patterns over hundreds to millions of years, Arauco peninsula, Chile. Journal of Geophysical Research: Solid Earth 114, B01407 (2009).

14 Shaw, J. H. \& Shearer, P. M. J. S. An elusive blind-thrust fault beneath metropolitan Los Angeles. Science 283, 1516-1518 (1999).

15 Baudon, C. \& Cartwright, J. A. 3D seismic characterisation of an array of blind normal faults in the Levant Basin, Eastern Mediterranean. Journal of Structural Geology 30, 746-760 (2008).

16 Yeats, R. S. Large-scale Quaternary detachments in Ventura basin, southern California. Journal of Geophysical Research: Solid Earth 88, 569-583 (1983).

17 Yeats, R. S. in Active Tectonics: Studies in Geophysics Vol. 163 - 79 (National Research Council, 1986).

18 Savage, J. C. A dislocation model of strain accumulation and release at a subduction zone. Journal of Geophysical Research: Solid Earth 88, 4984-4996 (1983).

19 Becker, T. W., Hashima, A., Freed, A. M. \& Sato, H. Stress change before and after the 2011 M9 Tohoku-oki earthquake. Earth Planetary Science Letters 504, 174-184 (2018).

20 Toda, S. \& Tsutsumi, H. Simultaneous reactivation of two, subparallel, inland normal faults during the M w 6.6 11 April 2011 Iwaki earthquake triggered by the M w 9.0 Tohoku-oki, Japan, earthquake. Bulletin of the Seismological Society of America 103, 15841602 (2011).

21 Melnick, D., Moreno, M., Motagh, M., Cisternas, M. \& Wesson, R. L. Splay fault slip during the Mw 8.82010 Maule Chile earthquake. Geology 40, 251-254, doi:10.1130/g32712.1 (2012).

22 Plafker, G. Surface faults on Montague Island associated with the 1964 Alaska earthquake. 42 (US Government Printing Office, 1967). 
23 Audin, L., Lacan, P., Tavera, H. \& Bondoux, F. Upper plate deformation and seismic barrier in front of Nazca subduction zone: The Chololo Fault System and active tectonics along the Coastal Cordillera, southern Peru. Tectonophysics 459, 174-185 (2008).

24 Barnes, P. M., Nicol, A. \& Harrison, T. Late Cenozoic evolution and earthquake potential of an active listric thrust complex above the Hikurangi subduction zone, New Zealand. Geological Society of America Bulletin 114, 1379-1405 (2002).

25 Singh, S., Hananto, N. \& Chauhan, A. Enhanced reflectivity of backthrusts in the recent great Sumatran earthquake rupture zones. Geophysical Research Letters 38, L04302 (2011).

26 Jara-Muñoz, J. et al. Quantifying offshore fore-arc deformation and splay-fault slip using drowned Pleistocene shorelines, Arauco Bay, Chile. Journal of Geophysical Research: Solid Earth 122, 4529-4558 (2017).

27 Wendt, J., Oglesby, D. D. \& Geist, E. L. Tsunamis and splay fault dynamics. Geophysical Research Letters 36, L15303 (2009).

28 Angermann, D., Klotz, J. \& Reigber, C. Space-geodetic estimation of the Nazca-South America Euler vector. Earth and Planetary Science Letters 171, 329-334, doi:http://dx.doi.org/10.1016/S0012-821X(99)00173-9 (1999).

29 Willner, A. P. et al. Time markers for the evolution and exhumation history of a Late Palaeozoic paired metamorphic belt in North-Central Chile $\left(34^{\circ}-35^{\circ} 30^{\prime} \mathrm{S}\right)$. Journal of Petrology 46, 1835-1858 (2005).

30 Hyppolito, T. et al. LP/HT metamorphism as a temporal marker of change of deformation style within the Late Palaeozoic accretionary wedge of central Chile. Journal of Metamorphic Geology 33, 1003-1024 (2015).

31 Willner, A. P., Richter, P. P. \& Ring, U. Structural overprint of a late Paleozoic accretionary system in north-central Chile (34-35 S) during post-accretional deformation. Andean Geology 36, 17-36 (2009).

32 Jara-Muñoz, J., Melnick, D., Brill, D. \& Strecker, M. R. Segmentation of the 2010 Maule Chile earthquake rupture from a joint analysis of uplifted marine terraces and seismiccycle deformation patterns. Quaternary Science Reviews 113, 171-192 (2015).

33 Moreno, M. et al. Toward understanding tectonic control on the Mw 8.8 2010 Maule Chile earthquake. Earth and Planetary Science Letters 321-322, 152-165, doi:http://dx.doi.org/10.1016/j.eps1.2012.01.006 (2012).

34 Lavenu, A. \& Encinas, A. Deformación frágil de los depósitos neógenos de la cuenca de Navidad (Cordillera de la Costa, 34 S, Chile central). Revista geológica de Chile 32, 229248 (2005).

35 Lange, D. et al. Aftershock seismicity of the 27 February $2010 \mathrm{Mw} 8.8$ Maule earthquake rupture zone. Earth and Planetary Science Letters 317-318, 413-425, doi:http://dx.doi.org/10.1016/j.eps1.2011.11.034 (2012). 
36 Ryder, I. et al. Large extensional aftershocks in the continental forearc triggered by the 2010 Maule earthquake, Chile. Geophysical Journal International 188, 879-890 (2012).

37 Schwanghart, W. \& Scherler, D. TopoToolbox 2-MATLAB-based software for topographic analysis and modeling in Earth surface sciences. Earth Surface Dynamics 2, 1-7 (2014).

38 Perron, J. T. \& Royden, L. An integral approach to bedrock river profile analysis. Earth Surface Processes Landforms 38, 570-576 (2013).

39 Lajoie, K. R. in Active Tectonics (ed R. Wallace) 95-124 (National Academy Press, 1986).

40 Jara-Muñoz, J., Melnick, D., Pedoja, K. \& Strecker, M. R. TerraceM-2: A Matlab® Interface for Mapping and Modeling Marine and Lacustrine Terraces. Frontiers in Earth Science 7, 1-18, doi:10.3389/feart.2019.00255 (2019).

41 Rohling, E. et al. Antarctic temperature and global sea level closely coupled over the past five glacial cycles. Nature Geoscience 2, 500-504 (2009).

42 Bintanja, R., van de Wal, R. S. \& Oerlemans, J. Modelled atmospheric temperatures and global sea levels over the past million years. Nature 437, 125 (2005).

43 Hayes, G. P. et al. Slab2, a comprehensive subduction zone geometry model. Science 362, 58-61 (2018).

44 Bookhagen, B., Echtler, H. P., Melnick, D., Strecker, M. R. \& Spencer, J. Q. G. Using uplifted Holocene beach berms for paleoseismic analysis on the Santa María Island, southcentral Chile. Geophysical Research Letters 33, L15302 (2006).

45 Lomnitz, C. Major Earthquakes of Chile: A Historical Survey, 1535-1960. Seismological Research Letters 75, 368-378, doi:10.1785/gssrl.75.3.368 (2004).

46 Dura, T. et al. Subduction zone slip variability during the last millennium, south-central Chile. Quaternary Science Reviews 175, 112-137 (2017).

47 Wells, D. L. \& Coppersmith, K. J. New empirical relationships among magnitude, rupture length, rupture width, rupture area, and surface displacement. Bulletin of the seismological Society of America 84, 974-1002 (1994).

48 Papazachos, B., Scordilis, E., Panagiotopoulos, D., Papazachos, C. \& Karakaisis, G. Global relations between seismic fault parameters and moment magnitude of earthquakes. Bulletin of the Geological Society of Greece 36, 1482-1489 (2004).

49 Richards, P. G. \& Aki, K. Quantitative seismology: theory and methods. Vol. I and II 700 (Freeman and Co., 1980).

50 King, G. C., Stein, R. S. \& Lin, J. Static stress changes and the triggering of earthquakes. Bulletin of the Seismological Society of America 84, 935-953 (1994). 
51 Bilek, S. L. \& Lay, T. Subduction zone megathrust earthquakes. Geosphere 14, 14681500 (2018).

52 Ye, L. et al. The 16 April 2016, MW 7.8 (MS 7.5) Ecuador earthquake: A quasi-repeat of the 1942 MS 7.5 earthquake and partial re-rupture of the 1906 MS 8.6 Colombia-Ecuador earthquake. Earth Planetary Science Letters 454, 248-258 (2016).

53 Lay, T. et al. Depth-varying rupture properties of subduction zone megathrust faults. Journal of Geophysical Research: Solid Earth 117, B04331 (2012).

54 Yang, G., Wu, J., Hu, Q. \& Cai, Y. Effects of static stress triggering of the strongest earthquakes along the Bengco - southeastern Piedmont of Nyainqentanglha mountain fault zone, Tibet. Journal of Seismology 23, 943-950 (2019).

55 Toda, S., Stein, R. S., Reasenberg, P. A., Dieterich, J. H. \& Yoshida, A. Stress transferred by the $1995 \mathrm{Mw}=6.9$ Kobe, Japan, shock: Effect on aftershocks and future earthquake probabilities. Journal of Geophysical Research: Solid Earth 103, 24543-24565 (1998).

56 Lockner, D. A. \& Beeler, N. M. Premonitory slip and tidal triggering of earthquakes. Journal of Geophysical Research: Solid Earth 104, 20133-20151 (1999).

57 Melnick, D. et al. Hidden Holocene slip along the coastal El Yolki fault in Central Chile and its possible link with megathrust earthquakes. Journal of Geophysical Research: Solid Earth 124, 7280- 7302 (2019).

58 Cortés-Aranda, J., González, G., Rémy, D. \& Martinod, J. Normal upper plate fault reactivation in northern Chile and the subduction earthquake cycle: From geological observations and static Coulomb Failure Stress (CFS) change. Tectonophysics 639, 118-131 (2015).

59 Coleman, A. J., Duffy, O. B. \& Jackson, C. A.-L. Growth folds above propagating normal faults. Earth-Science Reviews 196, 102885 (2019).

60 Hicks, S. P. et al. The $2010 \mathrm{Mw} 8.8$ Maule, Chile earthquake: Nucleation and rupture propagation controlled by a subducted topographic high. Geophysical Research Letters 39, L19308 (2012).

61 Morell, K. D., Regalla, C., Leonard, L. J., Amos, C. \& Levson, V. Quaternary rupture of a crustal fault beneath Victoria, British Columbia, Canada. GSA Today 27, 4-10 (2017).

62 Kelsey, H. M., Sherrod, B. L., Blakely, R. J. \& Haugerud, R. A. Holocene faulting in the Bellingham forearc basin: Upper-plate deformation at the northern end of the Cascadia subduction zone. Journal of Geophysical Research: Solid Earth 117, 1-26 (2012).

63 Liberty, L. M., Hemphill-Haley, M. A. \& Madin, I. P. The Portland Hills Fault: uncovering a hidden fault in Portland, Oregon using high-resolution geophysical methods. Tectonophysics 368, 89-103 (2003). 
64 Fujiwara, S. et al. Detection and interpretation of local surface deformation from the 2018 Hokkaido Eastern Iburi Earthquake using ALOS-2 SAR data. Earth, Planets and Space 71, 1-17 (2019).

65 Ishiyama, T., Sato, H., Kato, N., Nakayama, T. \& Abe, S. Active blind thrusts beneath the Tokyo metropolitan area: Seismic hazards and inversion tectonics. Geophysical Research Letters 40, 2608-2612 (2013).

66 Okada, Y. Surface deformation due to shear and tensile faults in a half-space. Bulletin of the Seismological Society of America 75, 1135-1154 (1985).

67 Beauducel, F. Matlab/Octave tools for geophysical studies, 2014).

68 Chiba, T., Kaneta, S.-i. \& Suzuki, Y. Red relief image map: new visualization method for three dimensional data. The international archives of the photogrammetry, remote sensing spatial information sciences 37, 1071-1076 (2008).

69 Ramsey, L. A., Walker, R. T. \& Jackson, J. Geomorphic constraints on the active tectonics of southern Taiwan. Geophysical Journal International 170, 1357-1372 (2007).

70 Whipple, K. X. \& Tucker, G. E. Dynamics of the stream-power river incision model: Implications for height limits of mountain ranges, landscape response timescales, and research needs. Journal of Geophysical Research: Solid Earth 104, 17661-17674 (1999).

71 Jara-Muñoz, J. \& Melnick, D. Unraveling sea-level variations and tectonic uplift in wave-built marine terraces, Santa María Island, Chile. Quaternary Research 83, 216-228 (2015).

72 Gallen, S. et al. Active simultaneous uplift and margin-normal extension in a forearc high, Crete, Greece. Earth and Planetary Science Letters 398, 11-24 (2014).

73 Thiel, C. et al. Luminescence dating of the Stratzing loess profile (Austria)-Testing the potential of an elevated temperature post-IR IRSL protocol. Quaternary International 234, 2331 (2011).

74 Galbraith, R. F., Roberts, R. G., Laslett, G., Yoshida, H. \& Olley, J. M. Optical dating of single and multiple grains of quartz from jinmium rock shelter, northern australia: part $\mathrm{i}$, experimental design and statistical models. Archaeometry 41, 339-364 (1999).

75 Huntley, D. \& Baril, M. The K content of the K-feldspars being measured in optical dating or in thermoluminescence dating. Ancient TL 15, 11-13 (1997).

76 Toda, S., Stein, R. S., Sevilgen, V. \& Lin, J. Coulomb 3.3 graphic-rich deformation and stress-change software for earthquake, tectonic, and volcano research and teaching-user guide. Report No. 2331-1258, 63 (US Geological Survey, 2011). 
Figures and Tables 


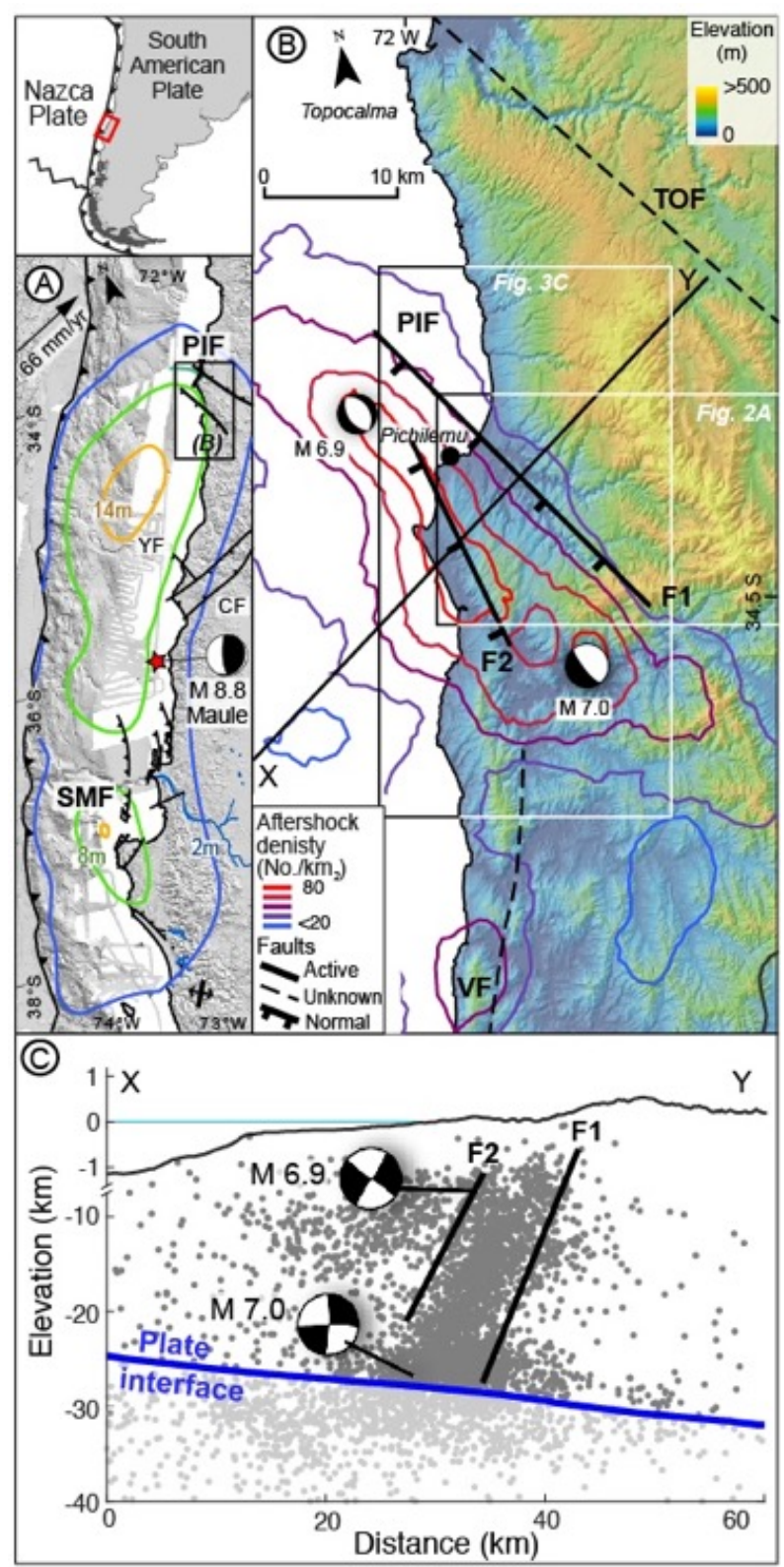

Figure 1: Tectonic setting of the Pichilemu Fault. A) Slip distribution of the 2010 Maule earthquake ${ }^{33}$. The Santa María (SMF) and Pichilemu (PIF) faults were reactivated by the earthquake ${ }^{3,21}$. YF: El Yolki Fault; CF: Carranza Fault. B) Topography (SRTM data from www2.jpl.nasa.gov) and Quaternary faults in the Pichilemu region. Contours show aftershock density after the Maule earthquake. Black thick lines denote the PIF branches (F1 and F2) and focal mechanisms of the PIF earthquakes (Farías et al., 2011). Location of Topocalma Fault (TOF), a Quaternary normal fault, and Vichuquén Fault 
(VF), an inferred fault affecting the crystalline basement ${ }^{31,34}$ are shown. C) Crustal profile showing aftershocks recorded between March 15 and September 30, 2010 (Lange et al., 2012), used to infer the subsurface geometry of the Pichilemu faults. Plate interface from Slab 2.0 model $^{43}$.

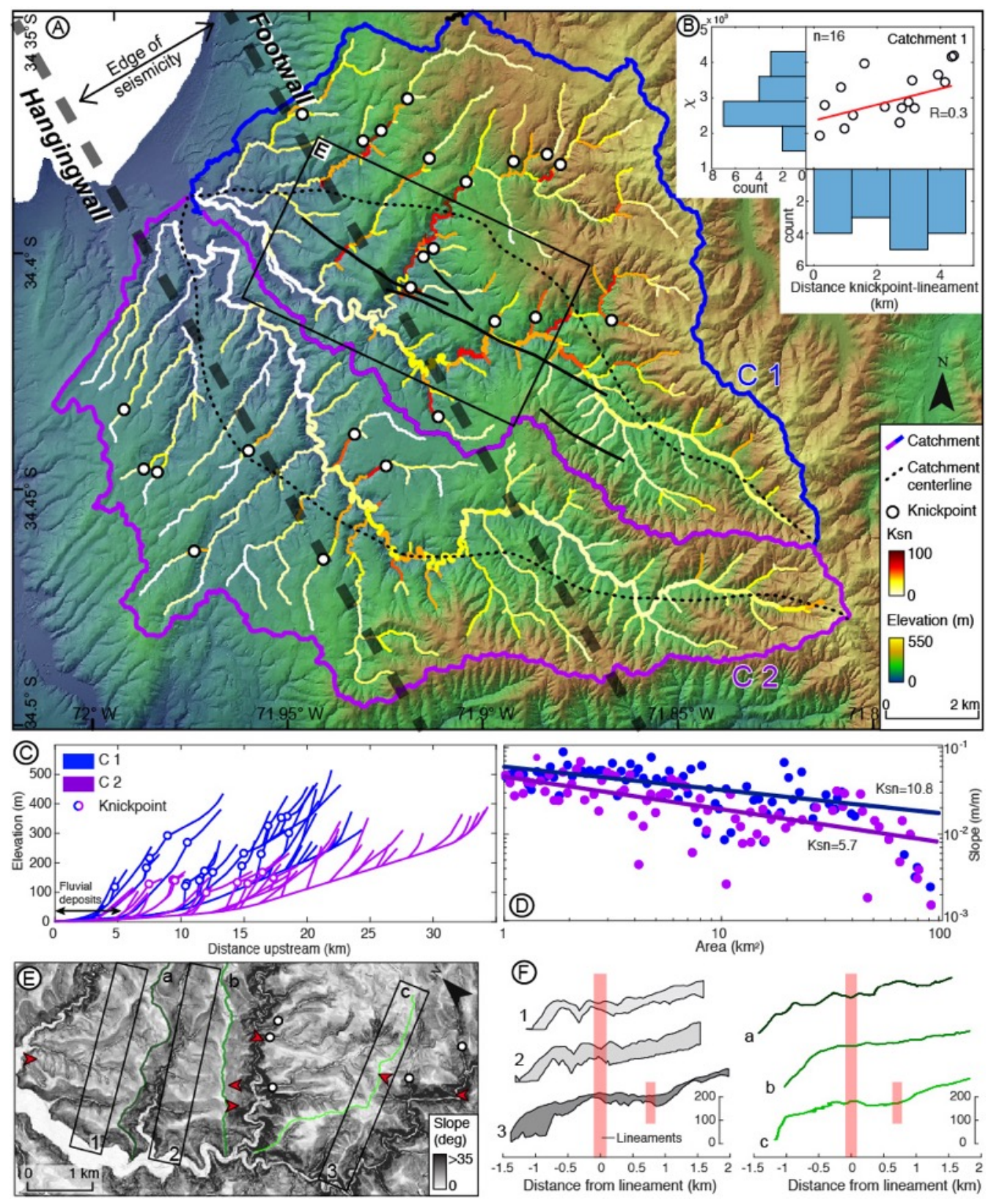

Figure 2: On-fault tectonic geomorphology from bare-earth LiDAR topography. A)

Shaded-relief map of the PIF coastal reach showing the two main catchments (C1 and $\mathrm{C} 2)$. 
Note asymmetry of the main trunks with respect to the catchment centreline. The black lines denote lineaments that may represent surface-reaching faults. Steepness index (Ksn) determined for a reference concavity of 0.45 . B) Scatter plots and histograms comparing fluvial and lineament metrics of $\mathrm{C} 1$. Scatter plot and histograms of chi-values $(\chi)$ at the location of knickpoints with respect to distance to lineament (See chi-map Fig. S2). C) Along river profiles of both catchments showing knickpoint locations. D) Slope-area plots of both catchments. Note that $\mathrm{C} 1$ has a higher Ksn value suggesting faster uplift rate. E) Slope map of lineaments and swath boxes shown in F. F) Swath and ridge-crest profiles. Note no clear relation with lineaments of evident scarps suggesting surface-breaching faults. (See Fig S1 for details on lineament mapping). 


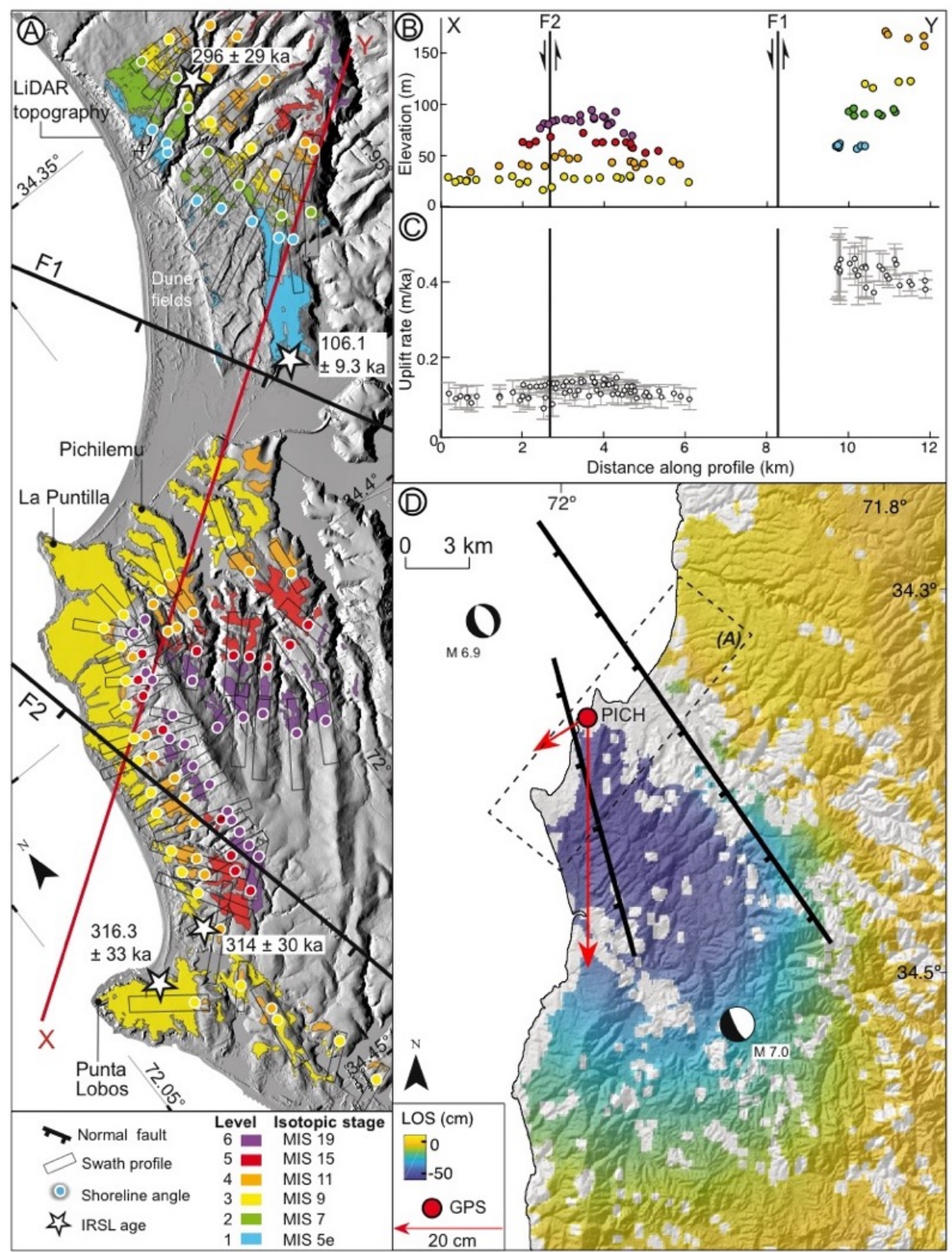

Figure 3: Coseismic and long-term surface deformation associated with the PIF. A)

Map of the six levels of marine terraces in the PIF area, boxes show location of swath profiles used to map shoreline angles (color-coded points). Black thick lines denote the two PIF branches (F1 and F2). B) Shoreline angles projected along profile X-Y, arrows indicate relative displacements of F1 and F2. C) Uplift rates deduced from shoreline angles along profile X-Y (details in methods). D) Coseismic Line of Sight (LOS) displacements in the Pichilemu area determined from Envisat ${ }^{\circledR}$ radar interferometry. Red 
arrows are vertical and horizontal displacements estimated at the continuous GPS station PICH (red dot) during the 2010 M7 earthquake ${ }^{36}$.

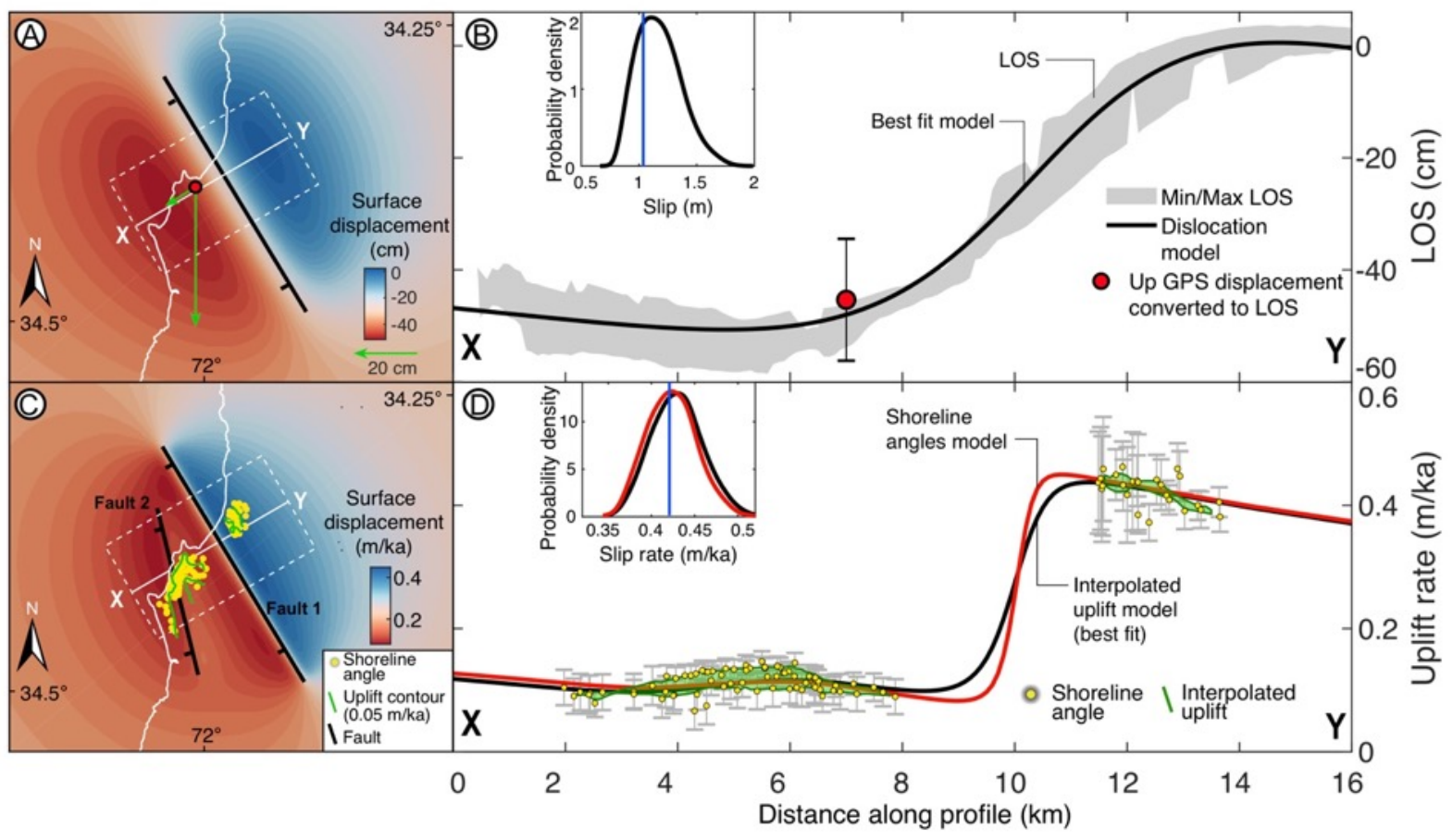

Figure 4: Coseismic and long-term fault-slip models. A) Best-fit model of Line of Sight (LOS) displacements during the 2010 PIF earthquakes (See methods for further details), green arrows denote vertical and horizontal displacements estimated at continuous GPS station $\mathrm{PICH}{ }^{36}$. B) Swath profile showing Envisat ${ }^{\circledR}$ LOS displacements and best-fit model. Red dot shows PICH displacement projected to LOS. C) Best-fit elastic model based on marine terrace uplift rates. D) Swath profile comparing uplift rates from shoreline angles (red line) and interpolated uplift rate surface (black line). Insets show probability-density distributions of slip and slip-rate values used to estimate confidence intervals of best-fit models (See Fig. S10 and methods); blue line denotes best fit slip and slip-rate of models in B and D. 

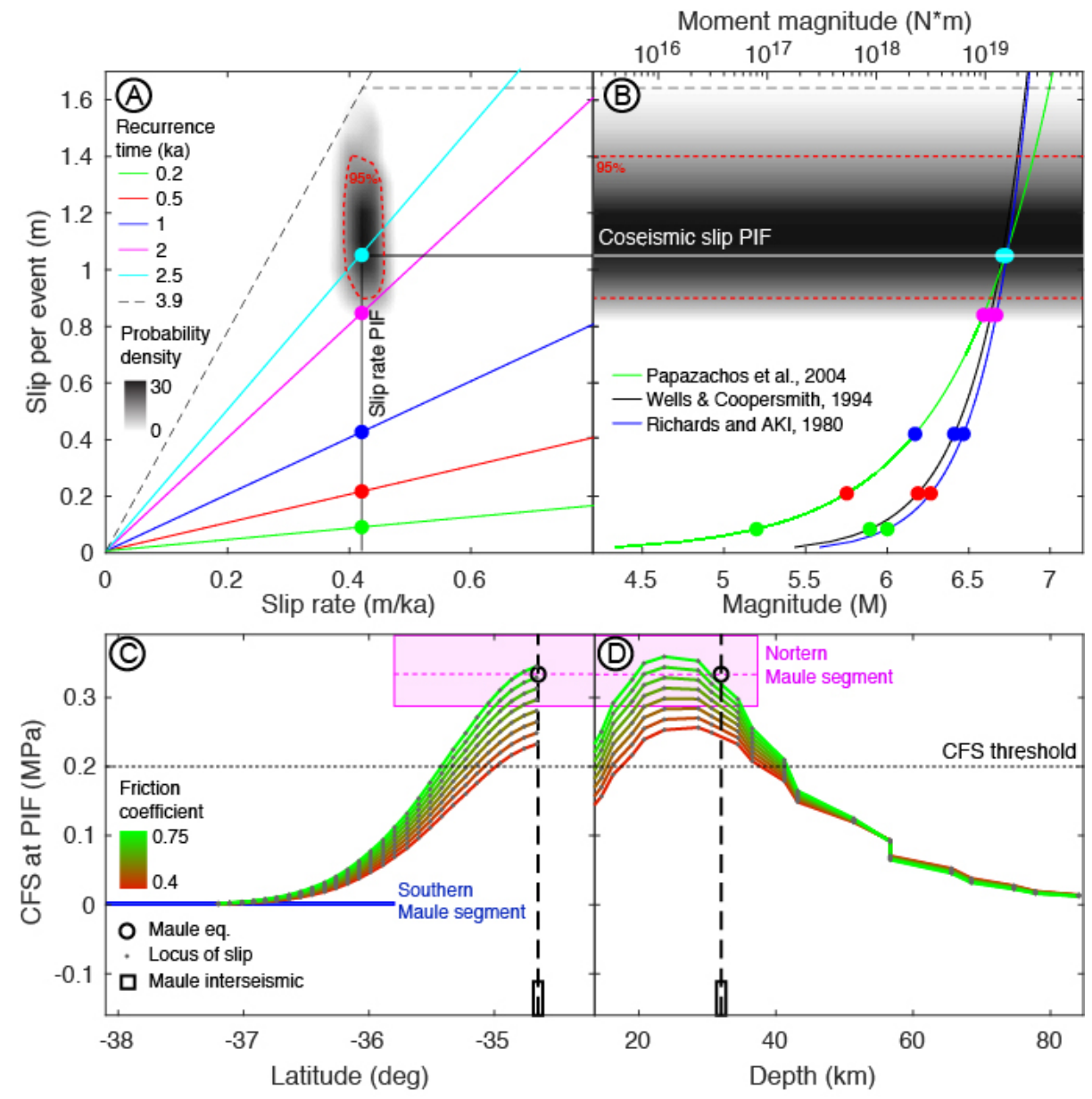

Figure 5: Recurrence time and reactivation scenarios of the PIF. A) Recurrence times estimated for different values of coseismic slip and long-term slip-rate, assuming that PIF slip occurs only during megathrust earthquakes. B) Equivalent moment magnitude for each recurrence time in A indicated as colour-coded points. Lines display different empirical relationships (see references in text). The grey area denotes the probabilitydensity of the PIF slip. The dashed red line in A and B shows the $95 \%$ confidence interval. The black and white lines in A and B show the best-fit slip per event and slip-rate. C) CFS values on PIF for different megathrust slip scenarios and friction coefficients along the Maule rupture. D) CFS values for different depths of megathrust slip at the northern part of the Maule rupture and friction coefficients. See text for details. 


\begin{tabular}{|c|c|c|c|c|c|c|c|c|c|c|c|c|}
\hline Sample & $\begin{array}{l}\text { Long } \\
\text { (deg) }\end{array}$ & $\begin{array}{c}\text { Lat } \\
\text { (deg) }\end{array}$ & $\begin{array}{c}\mathbf{Z} \\
(\mathbf{m})\end{array}$ & $\begin{array}{l}\text { Depth } \\
\text { (m) }\end{array}$ & $\begin{array}{l}\text { Paleodose } \\
\quad(\text { Gy) }\end{array}$ & $\begin{array}{l}\text { No. } \\
\text { aliquots }\end{array}$ & $\begin{array}{c}\text { Overdis } \\
\text { persion } \\
(\%)\end{array}$ & $\begin{array}{c}\mathbf{U} \\
(\mathbf{p p m})\end{array}$ & $\begin{array}{c}\text { Th } \\
(\mathbf{p p m})\end{array}$ & $\underset{(\%)}{K}$ & $\begin{array}{c}\text { Water } \\
(\%)\end{array}$ & $\begin{array}{l}\text { Age } \\
\text { (ka) }\end{array}$ \\
\hline PICH-1 & -71.97 & -34.38 & 51 & 2.80 & $242 \pm 13$ & 5 & 2 & $\begin{array}{c}1.44 \pm \\
0.07\end{array}$ & $\begin{array}{c}4.94 \pm \\
0.28\end{array}$ & $\begin{array}{c}0.86 \\
\pm \\
0.03 \\
\end{array}$ & $5 \pm 5$ & $106 \pm 9$ \\
\hline LOBO-1 & -72.04 & -34.42 & 14 & 3.20 & $748 \pm 58$ & 14 & 22 & $\begin{array}{c}0.96 \pm \\
0.05\end{array}$ & $\begin{array}{c}3.61 \pm \\
0.22\end{array}$ & $\begin{array}{c}1.09 \\
\pm \\
0.04\end{array}$ & $12 \pm 5$ & $328 \pm 33$ \\
\hline PICH-2 & -71.96 & -34.33 & 115 & 2.20 & $706 \pm 51$ & 19 & 22 & $\begin{array}{c}1.13 \pm \\
0.07\end{array}$ & $\begin{array}{c}5.32 \pm \\
0.34\end{array}$ & $\begin{array}{c}1.05 \\
\pm \\
0.01\end{array}$ & $6 \pm 5$ & $\begin{array}{c}297 \pm \\
29\end{array}$ \\
\hline PICH-4 & -72.03 & -34.42 & 38 & 6.5 & $784 \pm 54$ & 17 & 18 & $\begin{array}{c}1.18 \pm \\
0.07\end{array}$ & $\begin{array}{c}5.28 \pm \\
0.29\end{array}$ & $\begin{array}{c}1.20 \\
\pm \\
0.02 \\
\end{array}$ & $9 \pm 5$ & $\begin{array}{c}314 \pm \\
30\end{array}$ \\
\hline $\mathrm{SM} \mathrm{mb}$ & -73.51 & -37.04 & 2 & 0.5 & $3.4 \pm 0.1$ & 15 & 9 & - & - & - & - & - \\
\hline
\end{tabular}

Table 1. Post-IR IRSL samples. Radionuclide analyses include Uranium (U), Thorium (Th) and Potassium (K). Sample SM mb is a present-day beach berm sample from Santa Maria Island used to evaluate the completeness of signal resetting. 
Figures

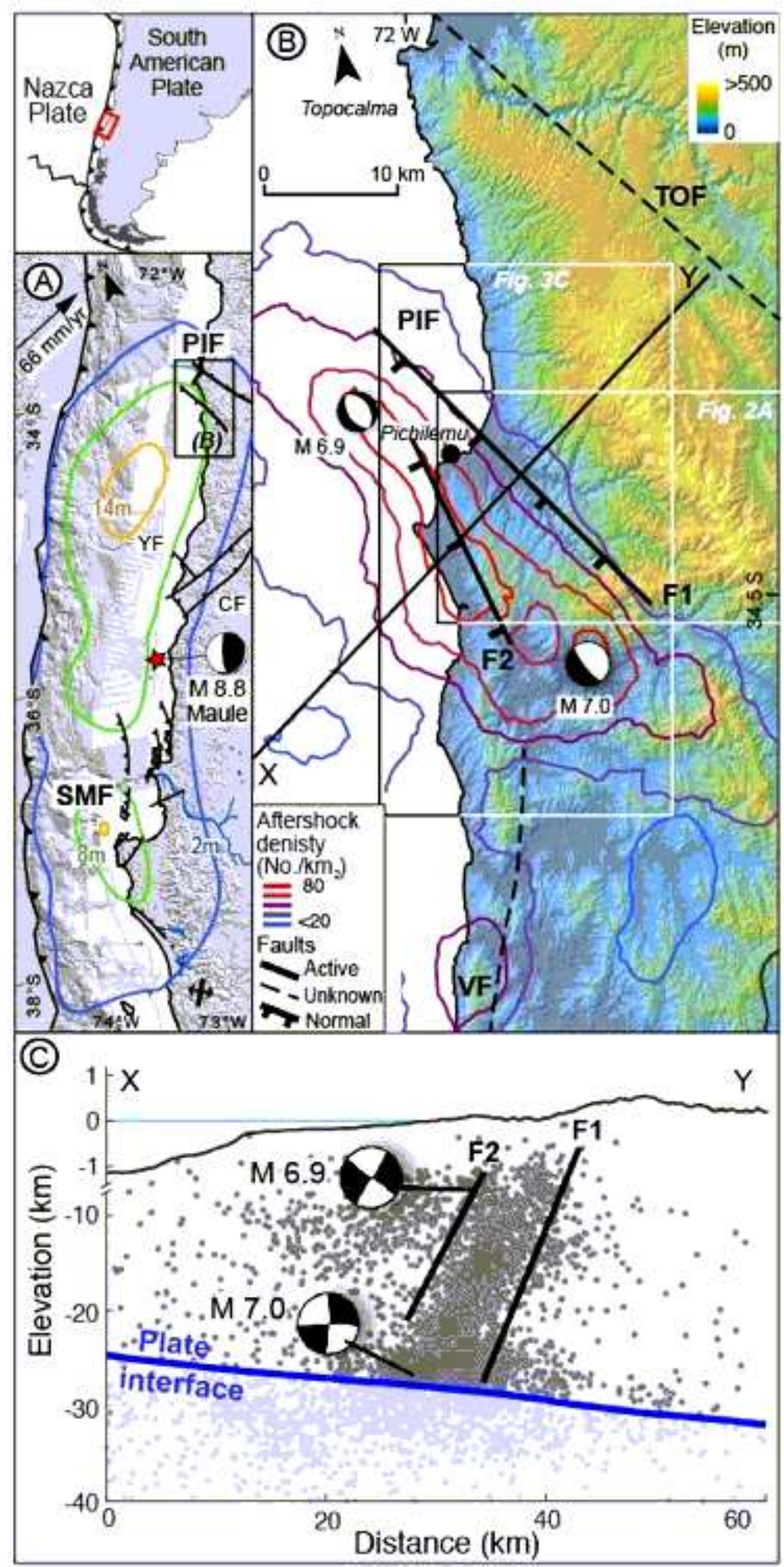

Figure 1

Tectonic setting of the Pichilemu Fault. A) Slip distribution of the 2010 Maule earthquake 33. The Santa María (SMF) and Pichilemu (PIF) faults were reactivated by the earthquake 3,21. YF: El Yolki Fault; CF: Carranza Fault. B) Topography (SRTM data from www2.jpl.nasa.gov) and Quaternary faults in the Pichilemu region. Contours show aftershock density after the Maule earthquake. Black thick lines denote 
the PIF branches (F1 and F2) and focal mechanisms of the PIF earthquakes (Farías et al., 2011). Location of Topocalma Fault (TOF), a Quaternary normal fault, and Vichuquén Fault (VF), an inferred fault affecting the crystalline basement 31,34 are shown. C) Crustal profile showing aftershocks recorded between March 15 and September 30, 2010 (Lange et al., 2012), used to infer the subsurface geometry of the Pichilemu faults. Plate interface from Slab 2.0 model 43.
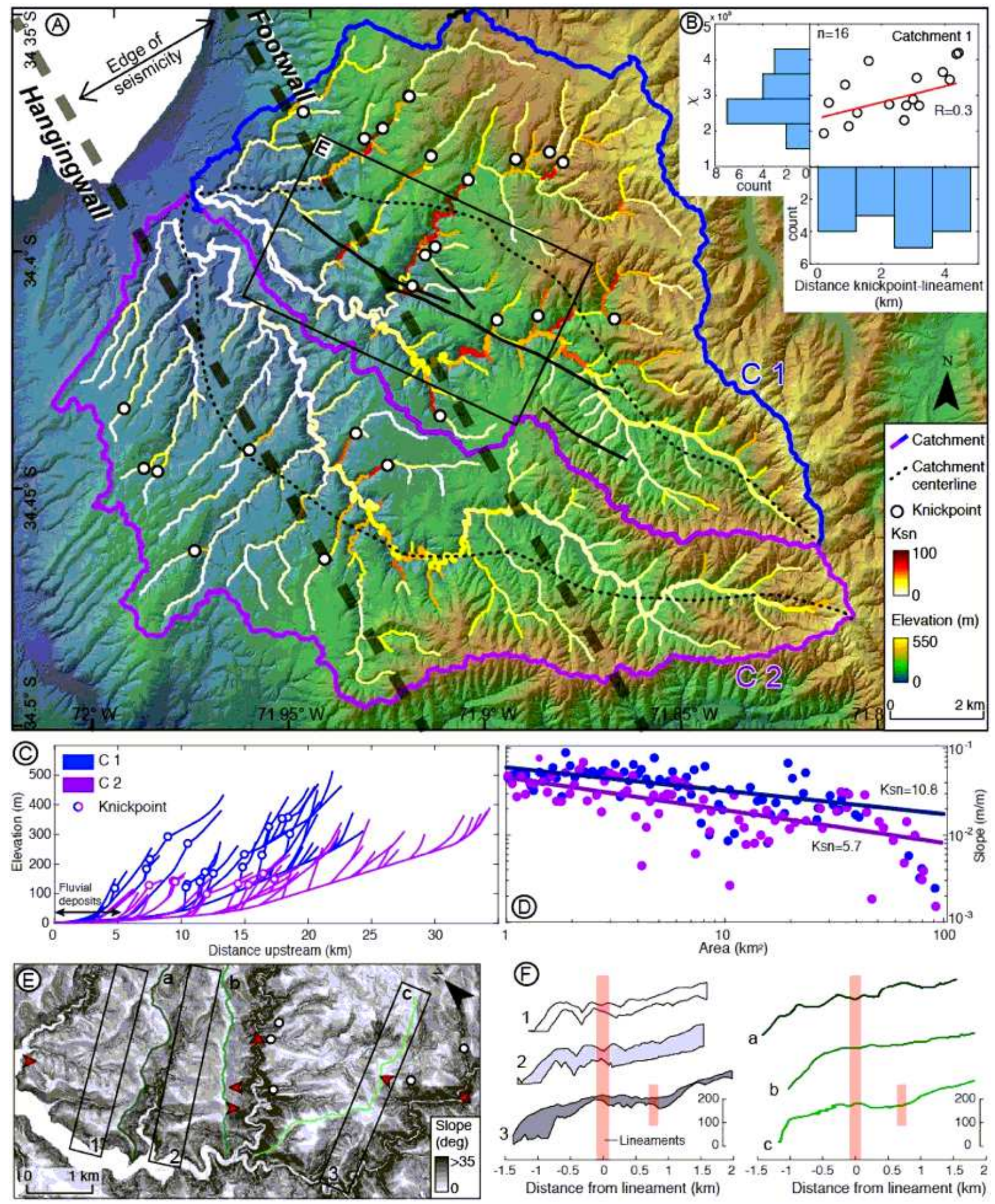

Figure 2 
On-fault tectonic geomorphology from bare-earth LiDAR topography. A) Shaded-relief map of the PIF coastal reach showing the two main catchments ( $\mathrm{C} 1$ and $\mathrm{C} 2)$. Note asymmetry of the main trunks with respect to the catchment centreline. The black lines denote lineaments that may represent surfacereaching faults. Steepness index (Ksn) determined for a reference concavity of 0.45 . B) Scatter plots and histograms comparing fluvial and lineament metrics of $\mathrm{C} 1$. Scatter plot and histograms of chi-values ( $\square$ ) at the location of knickpoints with respect to distance to lineament (See chi-map Fig. S2). C) Along river profiles of both catchments showing knickpoint locations. D) Slope-area plots of both catchments. Note that $\mathrm{C} 1$ has a higher Ksn value suggesting faster uplift rate. E) Slope map of lineaments and swath boxes shown in F. F) Swath and ridge-crest profiles. Note no clear relation with lineaments of evident scarps suggesting surface-breaching faults. (See Fig S1 for details on lineament mapping). 


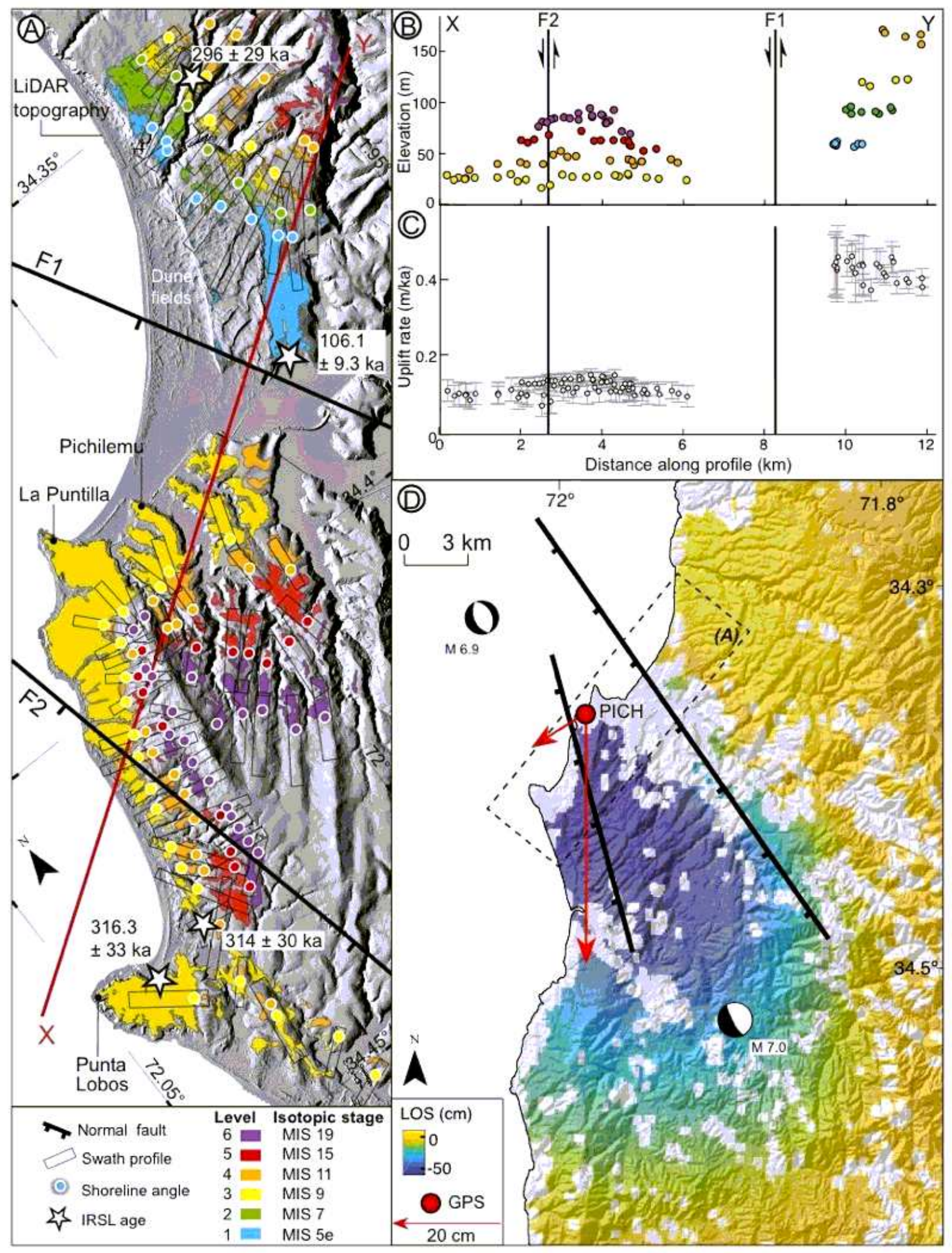

Figure 3

Coseismic and long-term surface deformation associated with the PIF. A) Map of the six levels of marine terraces in the PIF area, boxes show location of swath profiles used to map shoreline angles (color-coded points). Black thick lines denote the two PIF branches (F1 and F2). B) Shoreline angles projected along profile X-Y, arrows indicate relative displacements of F1 and F2. C) Uplift rates deduced from shoreline angles along profile X-Y (details in methods). D) Coseismic Line of Sight (LOS) displacements in the 
Pichilemu area determined from Envisat ${ }^{\circledR}$ radar interferometry. Red arrows are vertical and horizontal displacements estimated at the continuous GPS station PICH (red dot) during the 2010 M7 earthquake 36.

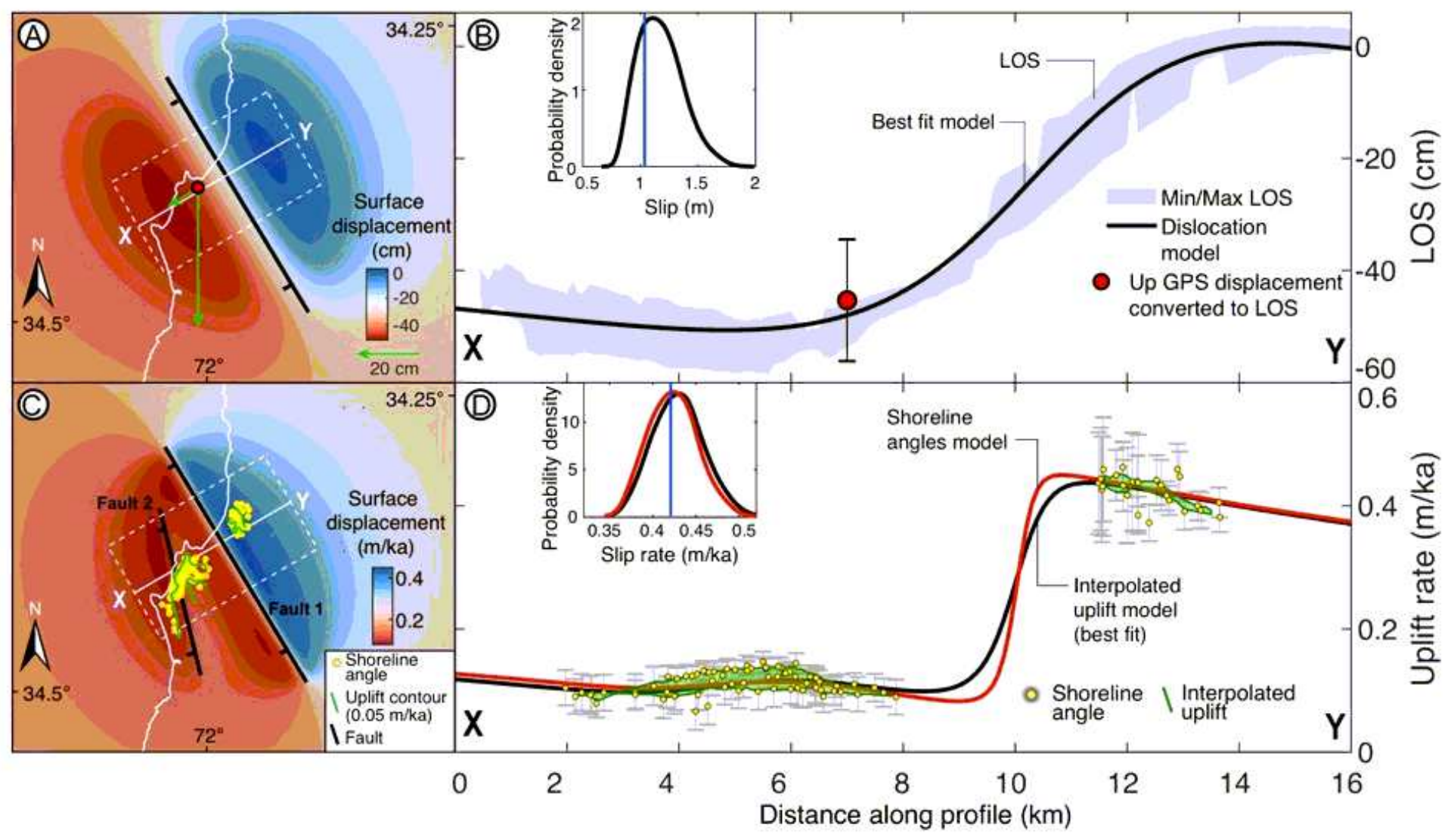

\section{Figure 4}

Coseismic and long-term fault-slip models. A) Best-fit model of Line of Sight (LOS) displacements during the 2010 PIF earthquakes (See methods for further details), green arrows denote vertical and horizontal displacements estimated at continuous GPS station PICH 36. B) Swath profile showing Envisat ${ }^{\circledR}$ LOS displacements and best-fit model. Red dot shows PICH displacement projected to LOS. C) Best-fit elastic model based on marine terrace uplift rates. D) Swath profile comparing uplift rates from shoreline angles (red line) and interpolated uplift rate surface (black line). Insets show probability-density distributions of slip and slip-rate values used to estimate confidence intervals of best-fit models (See Fig. S10 and methods); blue line denotes best fit slip and slip-rate of models in $B$ and $D$. 

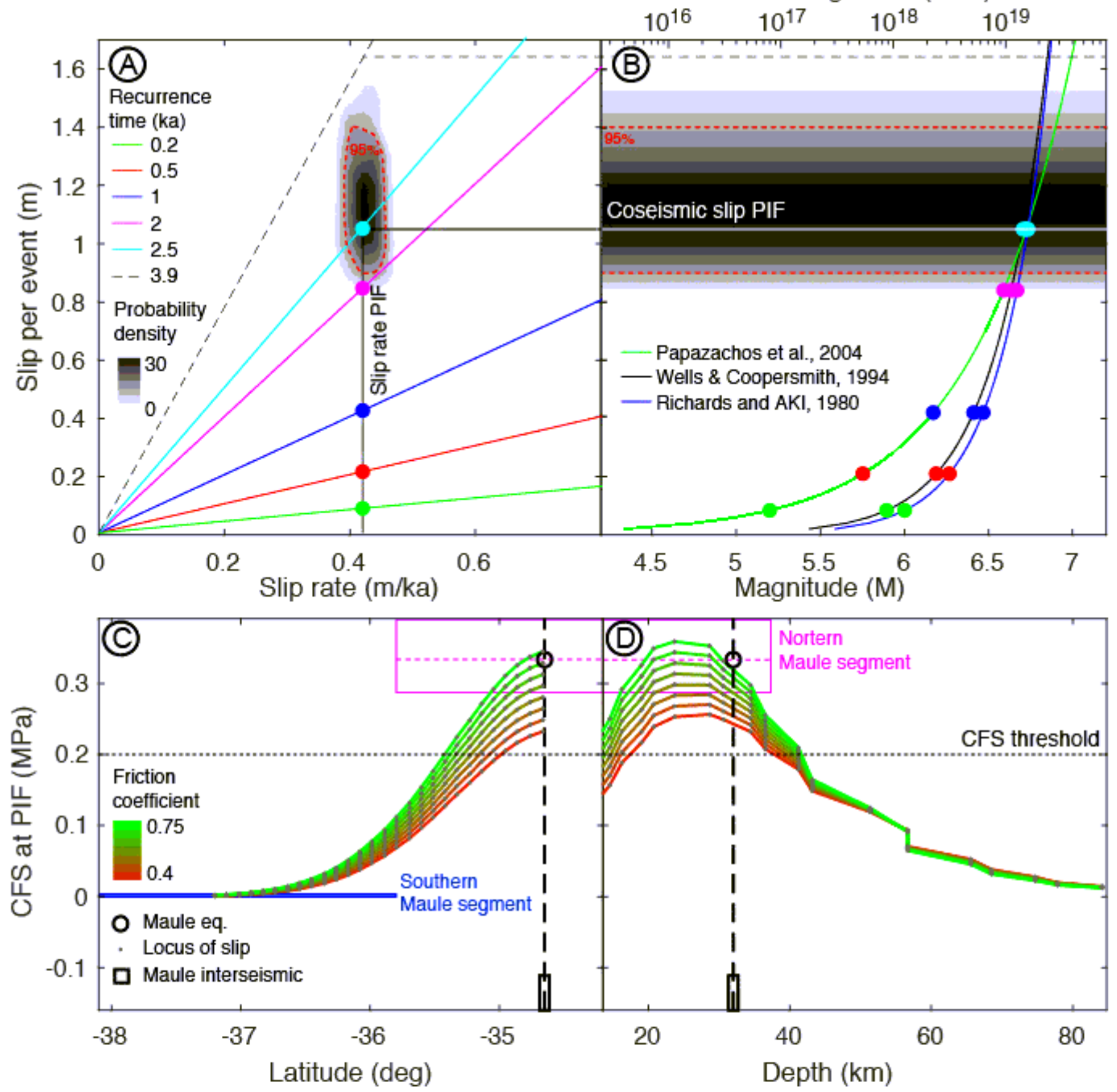

Figure 5

Recurrence time and reactivation scenarios of the PIF. A) Recurrence times estimated for different values of coseismic slip and long-term slip-rate, assuming that PIF slip occurs only during megathrust earthquakes. B) Equivalent moment magnitude for each recurrence time in A indicated as colour-coded points. Lines display different empirical relationships (see references in text). The grey area denotes the probability-density of the PIF slip. The dashed red line in A and B shows the $95 \%$ confidence interval. The black and white lines in A and B show the best-fit slip per event and slip-rate. C) CFS values on PIF for different megathrust slip scenarios and friction coefficients along the Maule rupture. D) CFS values for 
different depths of megathrust slip at the northern part of the Maule rupture and friction coefficients. See text for details.

\section{Supplementary Files}

This is a list of supplementary files associated with this preprint. Click to download.

- SUPPSAPIF101.doc 